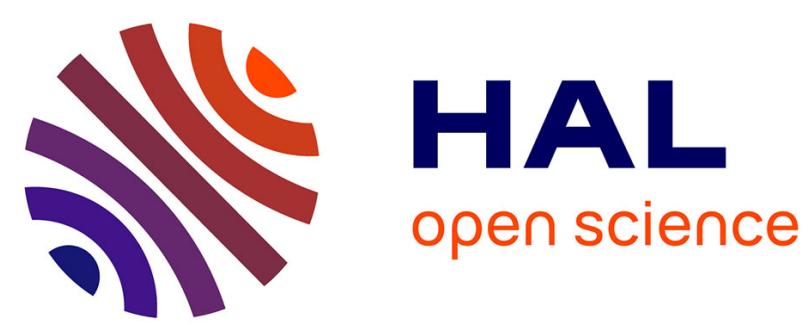

\title{
The Chicken and Egg Dilemma Linking Dunites and Chromitites in the Mantle-Crust Transition Zone beneath Oceanic Spreading Centres: a Case Study of Chromite-hosted Silicate Inclusions in Dunites Formed at the Top of a Mantle Diapir (Oman Ophiolite)
}

Mathieu Rospabé, Georges Ceuleneer, Vanessa Le Guluche, Mathieu Benoit, Mary-Alix Kaczmarek

\section{- To cite this version:}

Mathieu Rospabé, Georges Ceuleneer, Vanessa Le Guluche, Mathieu Benoit, Mary-Alix Kaczmarek. The Chicken and Egg Dilemma Linking Dunites and Chromitites in the Mantle-Crust Transition Zone beneath Oceanic Spreading Centres: a Case Study of Chromite-hosted Silicate Inclusions in Dunites Formed at the Top of a Mantle Diapir (Oman Ophiolite). Journal of Petrology, 2021, 62 (4), 10.1093/petrology/egab026 . hal-03403006

\author{
HAL Id: hal-03403006 \\ https://hal.science/hal-03403006
}

Submitted on 27 Oct 2021

HAL is a multi-disciplinary open access archive for the deposit and dissemination of scientific research documents, whether they are published or not. The documents may come from teaching and research institutions in France or abroad, or from public or private research centers.
L'archive ouverte pluridisciplinaire HAL, est destinée au dépôt et à la diffusion de documents scientifiques de niveau recherche, publiés ou non, émanant des établissements d'enseignement et de recherche français ou étrangers, des laboratoires publics ou privés. 
Draft Manuscript for Review

\section{The Chicken and Egg Dilemma Linking Dunites and Chromitites in the Mantle-Crust Transition Zone Beneath Oceanic Spreading Centres: A Case Study of Chromite- hosted Silicate Inclusions in Dunites Formed at the Top of a Mantle Diapir (Oman Ophiolite)}

\begin{tabular}{|r|l|}
\hline Journal: & Journal of Petrology \\
\hline Manuscript ID & JPET-Oct-20-0132.R2 \\
\hline Manuscript Type: & Original Manuscript \\
\hline Date Submitted by the & $\mathrm{n} / \mathrm{a}$ \\
\hline Complete List of Authors: & $\begin{array}{l}\text { Rospabé, Mathieu; JAMSTEC, Research Institute for Marine Geodynamics } \\
\text { (IMG); Géosciences Environnement Toulouse } \\
\text { Ceuleneer, Georges; Géosciences Environnement Toulouse, Observatoire } \\
\text { Midi-Pyrénées } \\
\text { Le Guluche, Vanessa; Géosciences Environnement Toulouse } \\
\text { Benoit, Mathieu; Géosciences Environnement Toulouse } \\
\text { Kaczmarek, Mary-Alix; Géosciences Environnement Toulouse }\end{array}$ \\
\hline Keyword: & $\begin{array}{l}\text { Oman ophiolite, Maqsad diapir, dunitic mantle-crust transition zone } \\
\text { (DTZ), disseminated chromites, silicate inclusions, melts/fluids } \\
\text { hybridization, reactive interfaces }\end{array}$ \\
\hline &
\end{tabular}

\section{SCHOLARONE" \\ Manuscripts}


The Chicken and Egg Dilemma Linking Dunites and Chromitites in the Mantle-Crust Transition Zone Beneath Oceanic Spreading Centres: A Case Study of Chromite-hosted Silicate Inclusions in Dunites Formed at the Top of a Mantle Diapir (Oman Ophiolite)

Mathieu Rospabé a,b,*, Georges Ceuleneer b, Vanessa Le Guluche b, Mathieu Benoit b, MaryAlix Kaczmarek ${ }^{b}$

${ }^{a}$ Research Institute for Marine Geodynamics (IMG), Japan Agency for Marine-Earth Science and Technology (JAMSTEC), 2-15 Natsushima, Yokosuka, Kanagawa 237-0061, Japan

b Géosciences Environnement Toulouse (GET), Observatoire Midi-Pyrénées, Université de Toulouse, CNRS, IRD, 14 avenue E. Belin, F-31400 Toulouse, France

\author{
*Corresponding Author: Mathieu Rospabé \\ Research Institute for Marine Geodynamics (IMG) \\ Japan Agency for Marine-Earth Science and Technology (JAMSTEC) \\ 2-15 Natsushima, Yokosuka 237-0061, Japan \\ E-mail: mrospabe@jamstec.go.jp
}




\section{ABSTRACT}

The mantle-crust boundary beneath oceanic spreading centres is a major chemical and thermal interface on Earth. Observations in ophiolites reveal that it is underlined by a dunitic transition zone (DTZ) that can reach a few hundred meters in thickness and hosting abundant chromitite ore bodies. The dunites have been deciphered as essentially mantle-derived in most ophiolitic massifs, i.e. reactional residues of interactions between peridotite and percolating melt(s). Although both dunite and chromitite in ophiolites have been the focus of many studies, the reasons of their systematic association remain unclear.

In this study we have explored the inclusion content of the chromite grains disseminated in the dunites from the DTZ exposed in the Maqsad area of the Oman ophiolite where a former asthenospheric diapir is exposed. Similarly to chromite in chromitite ore bodies, disseminated chromite grains in dunites contain a great diversity of silicate inclusions. Based on the major and minor element composition of 1794 single silicate inclusions in chromites from 285 samples of dunite and associated rocks in the DTZ, we infer that the disseminated chromites formed by a similar "metallogenic" process to the chromitites, and that, as a whole, dunites from the DTZ actually represent the low grade endmember of a single, giant ore body.

The nature of the silicate inclusions (amphibole and mica among others) enclosed in chromite grains in dunites from the Maqsad DTZ precludes their crystallization from an anhydrous primitive basaltic melt, and rather calls for a crystallization from a melt hybrid between common mafic melts and more exotic $\mathrm{Si}$-, $\mathrm{Na}$ - and volatile-rich fluids. The hybrid parent medium of both dunites and chromitites results from the interaction between an asthenospheric diapir (the MORB source), and a colder, altered lithospheric lid and hydrothermal fluids responsible for this alteration. The excess silica in the hybrid melt is provided by the 
incongruent dissolution of enstatite from mantle harzburgite and/or from moderate degree of partial melting of the altered gabbroic crust. The chemical composition of the silicate inclusions is more variable when enclosed in the disseminated chromites than in the chromitites, suggesting a greater variability of melts and/or fluids fractions involved in the genesis of dunites than of chromite ores. Finally, the DTZ can be viewed as a metamorphic contact aureole between episodically rising asthenospheric diapirs and formerly accreted axial lithospheric lids. Our conclusion about the chicken and egg dilemma linking dunites and chromitites beneath oceanic spreading centres (i.e. Do the chromitites form in response to the formation of dunites or conversely?) is that the mantle dunitization itself is a potential way for the release of $\mathrm{Cr}$ and its re-concentration as chromite ores, and that in turn the competition between orthopyroxene (+/- plagioclase) and chromite fractionation during this fluid/melt/peridotite reactional process is responsible of the great mineralogical and chemical variability of the DTZ dunites.

Key words: Oman ophiolite; Maqsad diapir; dunitic mantle-crust transition zone (DTZ); disseminated chromites; silicate inclusions; melts/fluids hybridization; reactive interfaces 


\section{INTRODUCTION}

In the mantle section of ophiolites, chromite ore bodies (chromitites) are, as a rule, surrounded by dunite (e.g. Cassard et al., 1981; González-Jiménez et al., 2014). This observation calls for a genetic link between the two. Dunites and chromitites are particularly abundant along the 'paleo-Moho', where dunites form a dunitic transition zone (DTZ) between the mantle and crustal sections (Moores and Vine, 1971; Greenbaum, 1972; Ceuleneer and Nicolas, 1985; Boudier and Nicolas, 1995; Abily and Ceuleneer, 2013). The development of a DTZ and more generally of dunites within the mantle section, and of the associated chromitites, is not restricted to a specific petrological context. They are present in ophiolites that evolved in tholeiitic (MORB-like) environments where they are associated with troctolites and olivine gabbros, and in depleted andesitic-boninitic environments where the associated lithologies include abundant pyroxenites (e.g. Quick, 1981a, 1981b; Augé, 1987; Ahmed and Arai, 2002; Varfalvy et al., 1996; Rollinson, 2005, 2008; Ceuleneer and le Sueur, 2008; Akizawa and Arai, 2009; Borisova et al., 2012; Abily and Ceuleneer; 2013; Rollinson and Adetunji, 2013). Both dunites and chromitites may result from melt-peridotite reactions in the shallow mantle (e.g. Arai and Yurimoto, 1994; Zhou et al., 1994; Allan and Dick, 1996; Borisova et al., 2012).

Deep-seated dunites associated with mantle harzburgites in ophiolites and in abyssal peridotites are interpreted as products of melt-peridotite reaction by most authors. Dunite formation can be explained by the simple fact that a mantle partial melt produced at depth and migrating to the surface is no longer multiply saturated with the peridotite mineral assemblage at low pressure (e.g. Stolper, 1980). Among other effects, it will induce the dissolution of residual orthopyroxene at shallow depth through the incongruent dissolution reaction leading to olivine precipitation and to the enrichment of the reactant melt in silica and other elements that are minor constituents of orthopyroxene (e.g. Al, $\mathrm{Cr}, \mathrm{Ca}, \mathrm{Na}$ ) as well as of clinopyroxene when 
present in the former peridotite (e.g. Dick, 1977; Quick, 1981b; Nicolas, 1986; Kelemen, 1990; Kelemen et al., 1992, 1995; Abily and Ceuleneer, 2013). From a historical perspective, this mechanism challenged the classical model of dunite formation by fractional crystallization from a high-Mg melt inspired by the seminal experimental studies of Bowen and widely supported by the study of rhythmic layering in layered intrusions. It is worth noting that Bowen (1927) realized that the fractional crystallization mechanism failed to account for the existence of large volumes of dunites, among other those documented in ophiolites.

In the frame of dunite genesis by melt-peridotite reaction, olivine grains of 'residual' origin (mantle-derived) and 'secondary' origin (precipitated after orthopyroxene dissolution) are intimately mixed, while their respective proportion may vary spatially at the scale of an outcrop. Other interstitial minerals (mostly chromite, clinopyroxene and plagioclase) in between olivine grains are interpreted as the crystallization products from percolating intergranular melts, consistent with observations at the outcrop and hand specimen scales in ophiolites and abyssal peridotites and with their geochemical signatures (e.g. Benn et al., 1988; Cannat et al., 1990; Ceuleneer, 1991; Girardeau and Francheteau, 1993; Boudier and Nicolas, 1995; Rampone et al., 1997; Koga et al., 2001; Kaczmarek and Müntener, 2008; Morgan et al., 2008; Abily and Ceuleneer, 2013; Sanfilippo et al., 2013; Dygert et al., 2016; Basch et al., 2018). In other words, dunites at the mantle-crust transition and more generally peridotites containing melt migration evidence are regarded as products of a multi-stage evolution leading to the intimate association of mineral assemblages issued from different processes: partial melting, reaction melting and crystallization of an interstitial melt (e.g. Rospabé et al., 2018 and references therein). The terms 'impregnation' and 'impregnated peridotite' have been introduced a long time ago (e.g. Bowen, 1915; Nicolas, 1986) to describe such complex lithologies for which the academic rock names based mostly on thin section scale microscopic observations of monogenic assemblages 
are not adapted descriptors. These terms are still of common use (e.g. Benn et al., 1988; Ceuleneer and Rabinowicz, 1992; Seyler et al., 2001; Dijkstra et al., 2003; Takazawa et al., 2007; Sanfilippo et al., 2013).

Petrologists realized early (e.g. Fisher, 1929) that the formation of large volumes of ore made almost exclusively of chromite was difficult to reconcile with the classical cumulate theory, i.e. factional crystallization followed by crystal/melt segregation. The arguments included mass balance considerations related among other to the poor solubility of $\mathrm{Cr}$ in silicate melts (e.g. Leblanc and Ceuleneer, 1991), and observation of the frequent association of chromite with minerals (both interstitial and included within chromite grains) that are not on the predicted cotectic at any stage of fractional crystallization of common basaltic melts (e.g. Irvine, 1975; Borisova et al., 2012). The issue concerned both thick layers of huge lateral extent in stratiform intrusions and pods reaching several hundred meters in size in ophiolites.

Based on the study of chromite ores in ophiolites and in continental layered intrusions, different mechanisms have been proposed to account for the mobilisation of $\mathrm{Cr}$ followed by the massive crystallization of chromite. They include among others (1) the mixing or 'hybridization' between a basalt saturated in $\mathrm{Cr}$ and a more silicic melt potentially issued from the country rocks assimilation or re-melting, (2) an $\mathrm{H}_{2} \mathrm{O}$ input, (3) the increase in the total pressure or $\mathrm{fO}_{2}$ of the parent magma, (4) the saturation in chromite alone in the parent magma following a decrease in the lithostatic pressure, or a combination of them (e.g. Irvine, 1975, 1977a, 1977b; Lipin, 1993; Bédard and Hébert, 1998; Matveev and Ballhaus, 2002; Spandler et al., 2005; Mondal and Mathez, 2006; Naldrett et al., 2012; Latypov et al., 2018). The silicate crystals included in chromite grains (e.g. amphibole, micas, orthopyroxene) are among the strongest pieces of evidence supporting the hypothesis of the silica- and/or $\mathrm{H}_{2} \mathrm{O}$-rich character of the 
parent melt in both ophiolites and layered intrusions (e.g. Johan et al., 1983, 2017; Talkington et al., 1984; McElduff and Stumpfl, 1991; Spandler et al., 2005; Borisova et al., 2012; Rollinson et al., 2018; Rospabé et al., 2019b), even if major differences in terms of intensive and extensive parameters of the system (e.g. melt/rock reaction processes vs. pure cumulates), of timing and of boundary conditions make the transposition from one setting to the other risky.

In the Oman ophiolite, the silicate inclusions in mantle and DTZ chromitite ore bodies have been reported in previous studies (Augé, 1987; Lorand and Ceuleneer, 1989; Leblanc and Ceuleneer, 1991; Schiano et al., 1997; Ahmed and Arai, 2002; Borisova et al., 2012; Rollinson et al., 2018; Zagrtdenov et al., 2018; Rospabé et al., 2019b). However, the disseminated chromites from the DTZ and the silicate inclusions they contain (Lorand, 1988; Rospabé et al., 2017) have never been studied with such a level of detail, even though they are an optimal target to make the connection between the formation of dunite and the formation of chromitite at mantle-crust transitions in the oceanic lithosphere. In the present study, we report on the nature and the major/minor element composition of silicate inclusions enclosed in chromite grains from 285 samples (dunites and related lithologies) collected along 17 cross-sections covering a large part of the DTZ in the Maqsad area (Sumail massif, Oman ophiolite). This allows us to anchor our discussion of the formation of dunite and chromitite on a robust data set, and to comprehend the spatial variations in the processes leading to their formation in the DTZ. We address the discussion about the question of the prior formation of dunites, without which chromitites cannot subsequently form, or reversely, in the 'chicken and egg dilemma' spirit to link these two melt/rock ( \pm fluids) reaction products.

\section{GEOLOGICAL BACKGROUND}

Geology of the Oman ophiolite 
The tectonic setting in which the Oman ophiolite formed is still debated. (1) The spatial distribution along the ophiolite of the nature of mafic dikes cutting-across the mantle section, and (2) the geochemical signature of lower crustal cumulates, attest that both MORB and depleted calc-alkaline series coexisted during the igneous evolution of the ophiolite (Benoit et al., 1999; Python and Ceuleneer, 2003; Yamasaki et al., 2006; Python et al., 2008; Clénet et al., 2010). The MORB kindred of the magmas that formed the crust accreted from the Maqsad diapir, focus of the present study, has been demonstrated by the crystallization sequences and by geochemical arguments (e.g. Benoit et al., 1996; Ceuleneer et al., 1996; Koga et al., 2001; Godard et al., 2003).

\section{Geology of the Maqsad Dunitic Transition Zone}

The Sumail massif is located in the southeast part of the Oman ophiolite (Fig. 1a). It exposes, in the Maqsad area, a former axial mantle upwelling evidenced by a characteristic hightemperature plastic deformation pattern recorded by mantle harzburgites (Rabinowicz et al., 1987; Ceuleneer et al., 1988; Ceuleneer, 1991; Jousselin et al., 1998). The Maqsad diapir fed a $\sim 80 \mathrm{~km}$-long, N130-oriented paleo-spreading segment with melts of MORB affinity (Python and Ceuleneer, 2003). The dunitic mantle-crust transition zone reaches its maximum thickness 
(up to $400 \mathrm{~m}$ ) above the central part of the Maqsad diapir where it seems to have developed preferentially. At the scale of geological maps $(1: 100,000)$, the contact between the mantle harzburgites and the dunitic transition zone (DTZ) is quite well defined. At the outcrop scale, where not faulted, it appears to be progressive on a few tens of meters, dunite bands interlayered with harzburgites becoming increasingly abundant upsection (Boudier and Nicolas, 1995). A thinner DTZ away from the centre of the diapir may be attributed to a less pronounced development of the dunites themselves, to the compaction of the dunitic mush and/or to the offaxis transposition and thinning related to corner flow (Rabinowicz et al., 1987; Ceuleneer, 1991; Jousselin et al., 2000).

Similarly to other mantle dunites and mantle-crust transitions in ophiolites or abyssal contexts, dunites from the Maqsad DTZ have been interpreted as replacive at the expense of mantle harzburgites rather than as pure cumulates (e.g. Rabinowicz et al., 1987; Boudier and Nicolas, 1995; Godard et al., 2000; Koga et al., 2001; Rospabé et al., 2017, 2018, 2019a). The two origins are, however, not mutually exclusive: it has been shown that in the uppermost 50 meters of the DTZ, minerals have chemical compositions consistent with the one of cumulates that prelude to the crystallization of the overlying layered troctolites and olivine gabbros, while in the main part of the DTZ (lowermost 250 meters), their composition supports a reactional origin (Abily and Ceuleneer, 2013).

The previous studies dedicated to the Maqsad DTZ evidenced an extremely variable modal content in dunites, evolving from 'pure dunites', made exclusively of olivine and of a few percent of interstitial chromite grains as well as very minor $(<0.5 \%)$ clinopyroxene, to dunites containing from few percent to up to $40 \%$ of interstitial minerals between olivine grains forming the matrix (Rabinowicz et al., 1987; Boudier and Nicolas, 1995; Koga et al., 2001; 
Abily and Ceuleneer, 2013; Rospabé et al., 2017, 2018, 2019a). The extensive mapping and the sampling of hundreds samples allowed estimating that about $40 \%$ pure dunites and $60 \%$ impregnated dunites constitute the DTZ in this area (Rospabé, 2018).

The interstitial minerals are mostly clinopyroxene and plagioclase developing frequently a poikilitic texture surrounding and isolating olivine grains as well as chromite (Rabinowicz et al., 1997; Boudier and Nicolas, 1995; Koga et al., 2001, Abily and Ceuleneer, 2013; Zagrtdenov et al., 2018). However, interstitial orthopyroxene and amphibole together with garnet and diopside, these latter with compositions intermediate between igneous and hydrothermal endmembers, have been recently discovered (Rospabé et al., 2017). Unexpected in the MORB environment in which the DTZ developed, and more generally the Maqsad-Sumail massif, these minerals have been shown to be the witnesses of the involvement of a hydrated and silica-rich melt or fluid in the formation of dunites in this context (Rospabé et al., 2017, 2018, 2019a). It was proposed, based on the increasing abundance of such peculiar interstitial minerals upsection within the DTZ, that the parent melt was hybrid between (1) the uprising MORB produced in depth by decompression melting within the diapir, and (2) a supercritical fluid rich in silica - hydrothermal in origin -, or potentially a trondhjemitic melt issued from the hydrated, partial re-melting of the country rocks.

Chromitite ore bodies are abundant in the Maqsad area (Ceuleneer and Nicolas, 1985). These ore bodies crop out mainly within the DTZ and in the shallowest $(<1 \mathrm{~km})$ horizon of the mantle section (Fig. 1b), in this latter case always surrounded by a dunitic envelope at the contact with host mantle harzburgites. Studies that focused on the Maqsad chromitites evidenced the occurrence of silicate crystals entrapped in chromite grains, including hydrated minerals and nominally anhydrous minerals derived from a hydrated parent melt. Clinopyroxene (diopside 
to augite), orthopyroxene (enstatite), amphibole (pargasite, hornblende) and mica (phlogopite, aspidolite) are among the most common (Leblanc and Ceuleneer, 1991; Schiano et al., 1997; Borisova et al., 2012; Rollinson et al., 2018; Zagrtdenov et al., 2018; Rospabé et al., 2019b). Base-metal sulphides and platinum-group minerals have also been described as inclusions in chromites in both dunites and chromitites (Lorand, 1988; Lorand and Ceuleneer, 1989; Leblanc et al., 1991). The silicate inclusions are similar to the ones observed in chromitites from other massifs in Oman (Augé, 1987; Ahmed and Arai, 2002), in other ophiolites (e.g. Johan et al., 1983, 2017; Talkington et al., 1984; Maibam et al., 2017; Wojtulek et al., 2019), in presentday ocean floor spinels in peridotites and chromitites (Arai and matsukage, 1998; Matsukage and Arai, 1998; Tamura et al., 2014, 2016), but also in chromite-rich layers in continental layered intrusions (e.g. McDonald, 1965; Ballhaus and Stumpfl, 1986; Li et al., 2005; Spandler et al., 2005; Friedrich et al., 2019).

In the Maqsad area, the similarity between (1) silicate inclusions in disseminated chromites, widespread in the DTZ, and (2) the interstitial phases in dunites on one hand, supports the involvement of the hydrated, hybrid melt as early as the upper oceanic mantle dunitization itself, and (3) with the silicate inclusions in larger chromitite podiforms on the other hand, supports the strong connection between the dunitization and the dissolution, transport and precipitation of $\mathrm{Cr}$ below oceanic ridges (Borisova et al., 2012; Rospabé et al., 2017, 2018, 2019a, 2020). However, the detailed relationships between the three components, interstitial minerals in dunites and inclusions in both disseminated chromites and more concentrated chromitites, remain poorly constrained in the context of ophiolitic dunites produced by fluid/melt/peridotite reactions, that contrasts for many aspects with dunite/chromitite cumulates observed in layered intrusions. 


\section{METHODS}

\section{Sampling strategy}

The regional dip of the Sumail massif is less than $10^{\circ}$ to the SE (i.e. the current lithologies stratigraphy closely matches to the original one). The cross-section sampling from deep to shallower levels with an interval of 10 to $20 \mathrm{~m}$ vertically has been shown to be an optimal scale to catch the petrological and geochemical trends across the DTZ (Abily and Ceuleneer, 2013; Rospabé et al., 2018, 2019a). The major element composition of silicate inclusions and of their host chromites was acquired for 285 samples collected along 17 cross-sections. Only the core of chromite was analysed, and we avoided the rims frequently altered into ferritchromite or magnetite. We observed that neither olivine nor chromite show significant zoning while interstitial phases like clinopyroxene can be zoned in major and minor elements (Rospabé et al., 2018).

\section{Analytical note}

The major and minor element contents of silicate inclusions and of their host chromite was measured in situ by electron microprobe, using a Cameca SXFive, a Cameca SXFiveFE (both at Centre de MicroCaractérisation Raimond Castaing, Toulouse, France) and a Cameca SX 100 (Microsonde Ouest, Brest, France). The data sets obtained using the different instruments were compared to make sure that there was no shift between the different instruments. Operating conditions for all analyses were: accelerating voltage: $20 \mathrm{kV}$; beam current: $20 \mathrm{nA}$; electron beam diameter: $1 \mu \mathrm{m}$; analysis counting time: $10 \mathrm{~s}$ on peak for each element, $5 \mathrm{~s}$ on backgrounds on both sides of the peak for each type of minerals. The following synthetic and natural minerals standards were used: albite $(\mathrm{Na})$, periclase $(\mathrm{Mg})$, corundum $(\mathrm{Al})$, sanidine $(\mathrm{K})$, wollastonite $(\mathrm{Si}$, $\mathrm{Ca})$, pyrophanite $(\mathrm{Mn}, \mathrm{Ti})$, hematite $(\mathrm{Fe})$, chromium oxide $(\mathrm{Cr})$, pure nickel $(\mathrm{Ni})$, sphalerite $(\mathrm{Zn})$, pure vanadium $(\mathrm{V})$, graftonite $(\mathrm{P})$, tugtupite $(\mathrm{Cl})$ and topaz $(\mathrm{F})$. The detection limits are 
$0.02 \mathrm{wt} \%$ for $\mathrm{Cl}, 0.03 \mathrm{wt} \%$ for $\mathrm{TiO}_{2}, \mathrm{Al}_{2} \mathrm{O}_{3}, \mathrm{Cr}_{2} \mathrm{O}_{3}, \mathrm{MgO}$ and $\mathrm{P}_{2} \mathrm{O}_{5}, 0.04 \mathrm{wt} \%$ for $\mathrm{SiO}_{2}$ and $\mathrm{Na}_{2} \mathrm{O}, 0.05 \mathrm{wt} \%$ for $\mathrm{CaO}$ and $\mathrm{K}_{2} \mathrm{O}, 0.06 \mathrm{wt} \%$ for $\mathrm{V}_{2} \mathrm{O}_{3}$ and $\mathrm{NiO}, 0.07 \%$ for $\mathrm{FeO}, \mathrm{MnO}, \mathrm{ZnO}$ and $\mathrm{F}$, for all mineral phases analysed. The internal precision ( $\% \mathrm{RSD})$ is better than $2 \%$ for major elements (e.g. $\mathrm{Cr}_{2} \mathrm{O} 3$ in chromite, $\mathrm{MgO}$ in olivine/orthopyroxene, $\mathrm{Al}_{2} \mathrm{O}_{3}$ in mica, amphibole), better than $6 \%$ for $\mathrm{TiO}_{2}$ (e.g. chromite, amphibole) and better than $25 \%$ for minor elements (e.g. $\mathrm{Na}_{2} \mathrm{O}$ in clinopyroxene, $\mathrm{NiO}$ in olivine).

The analytical strategy was to perform a systematic analysis of individual silicates present as inclusions in disseminated chromites all along the Maqsad DTZ, with the aim to get (1) a general, statistically significant overview of their nature, distribution and chemical variability at the scale of the DTZ, and (2) their relation with the variability of the composition of their host dunitic rocks. This led to the characterization of 1794 individual mineral phases (excluding alteration rims) present in a total of 1672 inclusions (1582 of them were monomineralic in the thin section plane) in 822 chromite grains from the 285 samples. We did not determine compositions of the bulk inclusions. All analyses are provided in Electronic Appendix 1.

\section{PETROGRAPHY AND DISTRIBUTION OF SILICATE INCLUSIONS HOSTED BY DISSEMINATED CHROMITES IN THE MAQSAD DTZ}

\section{Samples description}

We provide major element composition of silicate inclusions and of their host chromite in 9 mantle harzburgites $\left(\mathrm{n}_{\text {analyses }}=18\right), 1$ DTZ chromitite $\left(\mathrm{n}_{\text {analyses }}=15\right)$ and 275 dunites $\left(\mathrm{n}_{\text {analyses }}=\right.$ 1761). The dunites include $38.9 \%$ of pure dunites $(n=107$; olivine, chromite, very minor clinopyroxene) and $61.1 \%(n=168)$ of dunites containing various interstitial silicates in variable amounts (clinopyroxene, plagioclase, orthopyroxene and amphibole mainly). This 


\section{Chromite texture in DTZ dunites}

Chromite grains are present in all dunites, with no exception and independently from the occurrence of other interstitial minerals. They occur in variable proportions from a few disseminated grains with a typical modal content such as 1 or $2 \%$ to more concentrated levels and schlieren (Figs. 2 and 3). Grain size is generally close to $0.1-0.5 \mathrm{~mm}$ but can reach $2 \mathrm{~mm}$ in some samples and their shape is almost systemically rounded (Figs. 2a, b and 3); both size and distribution are heterogeneous at fine scale. Chromite is interstitial between olivine grains, and is more rarely enclosed in clinopyroxene oikocryst; chromite is never enclosed in olivine grains. Schlieren-type textures, or seams, are regularly observed along the DTZ (Figs. 1b, 2c, $\mathrm{d}$ and $3 \mathrm{c}, \mathrm{d})$. Samples that contain a particularly high amount of chromite regularly show an antinodular texture (Figs. 2e-g). Occasionally, chromitite dikelets cut across the DTZ, 
sometimes containing dunitic xenoliths (Fig. 2h), and in some places plurimetric massive chromitites form economic ore bodies (Fig. 1b). On a few outcrops chromitites are cross-cut by N130-oriented gabbro dikes (Fig. 2i, j), i.e. parallel to the strike of the paleo-ridge fed by the Maqsad diapir (Ceuleneer et al., 1996; Python and Ceuleneer, 2003).

\section{Diversity of silicate inclusions in DTZ chromites}

The nature and chemical composition of the silicate inclusions in disseminated chromite grains reveal the ubiquitous presence of clinopyroxene, olivine, amphibole, orthopyroxene, mica, and of minor other minerals as detailed below. The most common case is one or two inclusions by chromite grain, not present in all grains, which is possibly a bias related to the two-dimensional nature of thin section observations; in a given sample we never observed two populations of chromite, one devoid of inclusions, the other one containing numerous inclusions. Furthermore, peculiar distribution within a chromite grain, such as coronas of inclusions, a common feature in chromitite from this area (Zagrtdenov et al., 2018; Rospabé et al., 2019b), is rarely observed in the disseminated chromites in dunites. Silicate inclusions are generally round-shaped or euhedral equant square-shaped (so called 'negative crystals') (Fig. 4a-b), including only one phase (monomineralic inclusions) or several adjacent, imbricated crystals with clear contacts (polymineralic inclusions). The largest inclusions may be irregular in shape. Their diameter ranges from a few microns (in 2-D sections) to a maximum of about $100 \mu \mathrm{m}$, with a more frequent diameter of $40-50 \mu \mathrm{m}$. The contact between the included silicates and their host chromite is in many cases, but not systematically, underlined by a thin alteration rim at the contact with the host chromite. Alteration rims are generally present when the chromite is affected by small cracks (Fig. 4) but not only, being sometimes also associated with inclusions apparently unaffected by such cracks (Fig. 4a-b, f-h). In a few cases, a sulphide phase may be associated with silicates in a polymineralic inclusion, but both sulphides as well as platinum 
Figure 5a shows the relative frequency of occurrence as inclusion of each phase in all dunite samples. This frequency has been calculated on the basis of the presence (1) or absence (0) of each phase in each sample (total of 534 occurrences), reported in a percentage form (see Figure 5 caption). We observe by decreasing frequency of occurrence: pargasite and hornblende amphibole (amph), clinopyroxene of various compositions (cpx more abundant than diop, see just below), orthopyroxene (opx), olivine (ol), plagioclase (pl), garnet (gt), nepheline (ne), jadeite (jd), pectolite (pct), Na-rich near-albitic feldspar (alb), chlorapatite (Cl-ap). Concerning clinopyroxene, following Rospabé et al. (2017), the distinction is made between the diopside to augite having clearly an 'igneous' composition (i.e. consistent with a crystallization product of a basaltic melt), referred to as clinopyroxene or cpx, and the 'hybrid' diopside with composition intermediate between igneous cpx and gem diopside documented in hydrothermal systems and that do not plot along igneous fractional crystallization trends (called diopside or diop).

Amphibole (35.3\%) and clinopyroxene (28.1\%) are by far the two most widespread minerals in inclusion in disseminated chromite in the Maqsad DTZ, representing together nearly the two thirds of all the occurrences $(63.4 \%)$. The relative frequency of occurrence of other main phases (diopside, mica, olivine, orthopyroxene) is of $30.9 \%$ all together, ranging individually from 9.2 $\%$ (diopside) to $6.3 \%$ (orthopyroxene). Plagioclase and garnet represent together $3.8 \%$ of the occurrences. Nepheline and jadeite ( 0.8 and $0.6 \%$ respectively), reported for the first time in 
the Oman ophiolite with the exception of a stratiform chromitite cropping out at the base of the DTZ (Fig. 1b) (Rospabé et al., 2019b), and pectolite, albitic feldspar and apatite $(0.2 \%$ each) are very minor mineral phases in inclusions.

Figure $5 \mathrm{~b}$ represents the detailed relative frequency of occurrence as inclusions of the main phases in each type of dunite. Among the significant observations, we note that:

- Silicate inclusions in pure dunites are characterized by high relative frequencies of occurrence of both amphibole (39.2\%) and clinopyroxene (33.3\%), and less frequent occurrences of diopside (11.3\%), olivine (6.5\%), mica (5.4\%) and garnet (1.1 \%) among others. Orthopyroxene and plagioclase have never been observed as inclusion in chromite in pure dunites. On the contrary, nepheline and jadeite were observed only in pure dunites with the exception of jadeite also identified in only one cpx-bearing dunite.

- From cpx- to pl/cpx- to amph-bearing ( \pm opx/pl/cpx) dunites, we observe an increase in the relative frequency of occurrence of mica (from 6.3 to $14.4 \%$ ) and orthopyroxene (from 4.7 to $8.1 \%$ ), associated to the decreasing relative frequency of clinopyroxene (from 32.8 to $25.2 \%$ ) and diopside (from 17.2 to $6.8 \%$ ); the relative frequency of occurrence of diopside inclusions is particularly high in cpx-bearing dunites. Amphibole and olivine do not display a clear evolution of their relative frequency of occurrence from a dunite type to another. Feldspar plagioclase and garnet are minor occurrences in $\mathrm{pl} / \mathrm{cpx}$-bearing dunites and amph-bearing dunites. The only one pectolite has been identified in an $\mathrm{amph} / \mathrm{pl} / \mathrm{cpx}$-bearing dunite.

- From other impregnated dunites to opx/pl/cpx-bearing dunites are observed much frequent relative occurrences of orthopyroxene $(20.3 \%)$, plagioclase $(6.8 \%)$ and garnet $(5.4 \%)$, and less frequent occurrences of clinopyroxene (14.9\%) and diopside (2.7). The rare occurrences of 1 albitic feldspar and of $1 \mathrm{Cl}$-apatite in inclusion have been previously reported concerning opx/pl/cpx-bearing dunites (Rospabé et al., 2020). 
Figures $5 \mathrm{c}$ and $5 \mathrm{~d}$ summarize the evolution of the nature of the silicate inclusions in chromite from a dunite type to another. From pure dunites to $\mathrm{cpx}-$ and $\mathrm{pl} / \mathrm{cpx}$-bearing, and especially to amph-bearing and opx/pl/cpx-bearing dunites, we observe the decrease of the sum of individual occurrences of olivine, clinopyroxene and plagioclase in inclusion on one hand (i.e. the anhydrous mineral assemblage expected from crystallization of an olivine tholeiite at low pressure, consistent with the MORB igneous environment of the Maqsad area), and the increase of the sum of individual occurrences of the more 'exotic' (i.e. witnesses of a more siliceous and hydrated parent melt) amphibole, mica and orthopyroxene in inclusion on the other hand. (Fig. 5c). This evolution is still observed when diopside and garnet are taken into account together in addition with the amph-opx-mica association (Fig. 5d). This demonstrates the existence of a strong relationship between the nature of silicate inclusions in disseminated chromites within the DTZ and the nature of interstitial minerals in their host dunites (Borisova et al., 2012; Rospabé et al., 2017, 2020). This evolution in the inclusions content from a host rock type to another is interestingly not related to the modal abundance of the interstitial minerals in the host dunites but only to their occurrence, even where present in minor amounts.

\section{Distribution of silicate inclusions across the DTZ}

Inclusions in disseminated chromites in dunites are observed all across the Maqsad DTZ (Fig. 6). Taken individually, whatever they form monomineralic inclusions or are associated in polymineralic inclusions, amphibole and clinopyroxene occur from the base to the top of the DTZ. Diopside, mica, and olivine inclusions are observed mainly within the altitude interval $700 \mathrm{~m}$ to $1100-1150 \mathrm{~m}$. Orthopyroxene inclusions occur only above $850 \mathrm{~m}$ (i.e. about 200-250 above the base of the DTZ), as does interstitial orthopyroxene in the surrounding matrix. In detail, orthopyroxene inclusions are observed exactly at the two same altitude intervals where 
interstitial orthopyroxene occurs (as well as along a third shallower and thinner level for only three occurrences) (Fig. 6). It is interesting to note that the chromitite ore bodies and chromititerich intervals in the Maqsad DTZ occur at the same altitude as the three opx inclusions-bearing levels. Both garnet and plagioclase inclusions are mostly restricted to the lower opx-rich level (interstitial garnet and plagioclase in the matrix are widespread at a much larger scale along the DTZ). By the same way, the rare nepheline, jadeite, pectolite, $\mathrm{Cl}$-apatite and near-albitic feldspar inclusions are only observed above the altitude of $850 \mathrm{~m}$.

\section{MAJOR ELEMENT MINERAL COMPOSITIONS}

Here below are briefly described the most significant chemical features of chromite and of the main mineral phases they contain in inclusion (amph, cpx and diop, mica, ol, opx, gt, pl). A more detailed description of the chemical major element composition of all types of silicate inclusions together with extended diagrams are provided in Electronic Appendix 2.

\section{Chromite}

Disseminated chromites in dunites from the Maqsad DTZ show broad compositional ranges. They are characterized by $\mathrm{XCr}(100 \times$ molar $\mathrm{Cr} /(\mathrm{Cr}+\mathrm{Al}))=38.8-69.6 \mathrm{~mol} \%, \mathrm{XMg}(100 \times$ molar $\left.\mathrm{Mg} /\left(\mathrm{Mg}+\mathrm{Fe}^{2+}\right)\right)=32.7-68.1 \mathrm{~mol} \%, \mathrm{YFe}^{3+}\left(100 \times\right.$ molar $\left.\mathrm{Fe}^{3+} /\left(\mathrm{Cr}+\mathrm{Al}+\mathrm{Fe}^{3+}\right)\right)=1.23-$ $18.3 \mathrm{~mol} \%$ and $\mathrm{TiO}_{2}=0.11-1.25 \mathrm{wt} \%$ (Fig. 7a, b).

Among the most significant contrasts between the different dunite groups, amph-bearing and especially opx/pl/cpx-bearing dunites generally display higher $\mathrm{XCr}$ values, mainly higher than 55 in spite of an overlapping at lower values, and $\mathrm{TiO}_{2}$ content, higher than $0.5 \mathrm{wt} \%$, than in other dunites. Accordingly, two trends can be defined in diagrams showing the evolution of the $\mathrm{TiO}_{2}$ content as a function of $\mathrm{XCr}$ (Fig. 7b): it increases much faster at a given $\mathrm{XCr}$ in amph- 
and especially opx/pl/cpx-bearing dunites than in pure and cpx-bearing dunites; chromite in $\mathrm{pl} / \mathrm{cpx}$-bearing dunites shows intermediate composition.

\section{Silicate inclusions}

The chemical composition of the main silicate inclusions is described following their decreasing frequency of occurrence as presented in Figure 5a.

\section{Amphibole}

Amphibole inclusions are mainly $\mathrm{Cr}-$, $\mathrm{Ti}-$, Na- rich pargasites/pargasitic hornblendes $(\sim 60 \%)$, magnesio-hastingsites/magnesio-hastingsitic hornblendes $(\sim 30 \%)$, and more rarely edenitic hornblendes, kaersutites or tschermakitic hornblendes ( $10 \%)$. They display extensive chemical variations in $\mathrm{XMg}$, from 83.8 to $95.0 \mathrm{~mol} \%$, and in $\mathrm{Al}_{2} \mathrm{O}_{3}\left(7.74-15.7\right.$ wt \%), $\mathrm{Cr}_{2} \mathrm{O}_{3}$ $(0.04-5.95 \mathrm{wt} \%)$ and $\mathrm{TiO}_{2}(0.10-4.95 \mathrm{wt} \%)$ contents. The variations in $\mathrm{Na}_{2} \mathrm{O}(1.36-5.27 \mathrm{wt} \%)$ and $\mathrm{K}_{2} \mathrm{O}$ (near detection limits to 1.42 wt \%) contents allow defining a XNa $(100 \times$ molar $\mathrm{Na} /(\mathrm{Na}+\mathrm{K}))$ evolving from 70.3 to $100.0 \mathrm{~mol} \%$. The amphibole inclusions for which $\mathrm{P}_{2} \mathrm{O}_{5}$, $\mathrm{Cl}$ and $\mathrm{F}$ contents were determined show variations from detection limits to $0.30 \mathrm{wt} \%$ (mean $0.05 \mathrm{wt} \%$ ), $0.24 \mathrm{wt} \%$ (mean $0.03 \mathrm{wt} \%$ ), and $0.48 \mathrm{wt} \%$ (mean $0.12 \mathrm{wt} \%$ ) respectively.

The composition of amphibole included in chromite is related to the nature of the host rock, especially the $\mathrm{Al}_{2} \mathrm{O}_{3}$ and $\mathrm{TiO}_{2}$ contents. The $\mathrm{Al}_{2} \mathrm{O}_{3}$ content in pure and cpx-bearing dunites spans the entire variation range, with a clear increase with the decrease of XMg (Fig. 8a). On the contrary, the $\mathrm{Al}_{2} \mathrm{O}_{3}$ content in opx/pl/cpx-bearing dunites is lower than $12.1 \mathrm{wt} \%$ and shows a gentle decrease with $\mathrm{XMg}$ (pl/cpx- and amph-bearing dunites have an intermediate composition). The concentration in $\mathrm{TiO}_{2}$ in amphibole inclusions increases from pure dunites (0.29-3.51 wt \%) to cpx-, pl/cpx-, amph-, then opx/pl/cpx-bearing dunites (1.67-4.95 wt \%). 
The $\mathrm{TiO}_{2}$ content likewise displays a dichotomous chemical distribution (Fig. 8b): it decreases together with $\mathrm{XMg}$ in pure dunites and partly in cpx-bearing dunites, increases with the decreasing $\mathrm{XMg}$ in amph- and opx/pl/cpx-bearing dunites, and shows a behaviour intermediate between the two trends in part of cpx- and in all pl/cpx-bearing dunites. Variations in both the $\mathrm{Na}_{2} \mathrm{O}$ and $\mathrm{Cr}_{2} \mathrm{O}_{3}$ contents look more scattered when all data are plotted together, but in details as shown in Electronic Appendix 2, they appear to distribute among two distinct trends according to the lithology of the host rock.

\section{Clinopyroxene}

Clinopyroxenes in inclusion in chromites display $\mathrm{XMg}=85.1-96.3 \mathrm{~mol} \%, \mathrm{Al}_{2} \mathrm{O}_{3}=0.60-5.65$ wt $\%, \mathrm{Cr}_{2} \mathrm{O}_{3}=0.18-5.00$ wt $\%, \mathrm{Na}_{2} \mathrm{O}=0.04-1.98$ wt $\%$ and $\mathrm{TiO}_{2}=0.05-1.96$ wt $\%$. The $\mathrm{Al}_{2} \mathrm{O}_{3}$ content globally increases with the decrease of the $\mathrm{XMg}$ (Fig. 9a). The $\mathrm{TiO}_{2}$ and $\mathrm{Na}_{2} \mathrm{O}$ basically increases and decreases respectively from pure dunites (averaged $\mathrm{TiO}_{2}=0.29 \mathrm{wt} \%$ and $\mathrm{Na}_{2} \mathrm{O}$ $=0.66 \mathrm{wt} \%$ ) to opx $/ \mathrm{pl} / \mathrm{cpx}$-bearing dunites (averaged $\mathrm{TiO}_{2}=0.53 \mathrm{wt} \%$ and $\mathrm{Na}_{2} \mathrm{O}=0.40 \mathrm{wt}$ $\%$ ); compositions are intermediate in inclusions in other dunites (Fig. 9b). The distribution of the variations in $\mathrm{Cr}_{2} \mathrm{O}_{3}$ as a whole seems random with no particular evolution, similarly to what is observed in the amphibole composition. In detail, this only concerns clinopyroxene in pure dunites while the global random distribution results from the overprint of two reverse trends, with on one hand the common decrease of $\mathrm{Cr}_{2} \mathrm{O}_{3}$ and $\mathrm{XMg}$ in inclusions in cpx- and pl/cpxbearing dunites, and on the other hand the increase of the $\mathrm{Cr}_{2} \mathrm{O}_{3}$ content when $\mathrm{XMg}$ decreases in amph- and opx/pl/cpx-bearing dunites (Electronic supplement 2).

\section{Diopside}

As explained here above, inclusions in chromite characterized as 'diopsides' display compositions intermediate between 'igneous' clinopyroxene and pure hydrothermal diopsides 
(Fig. 10) (a distinction introduced in Rospabé et al., 2017). Their XMg (90.7-97.7 mol \%) is higher than in the clinopyroxene inclusions described above. On the contrary, their $\mathrm{Al}_{2} \mathrm{O}_{3}(0.01$ 2.46 wt \%), $\mathrm{Cr}_{2} \mathrm{O}_{3}\left(0.08-1.85\right.$ wt \%), $\mathrm{TiO}_{2}\left(0.01-0.57\right.$ wt \%) and $\mathrm{Na}_{2} \mathrm{O}(0.02-0.94$ wt \%) contents, which all decrease with the increasing of XMg (Fig. 10), are lower, especially in the opx/pl/cpx-bearing dunites.

\section{Mica}

Mica in inclusion shows a composition evolving from phlogopite to aspidolite (Na-phlogopite). The $\mathrm{Na}_{2} \mathrm{O}$ and $\mathrm{K}_{2} \mathrm{O}$ contents range from 0.12 to $8.10 \mathrm{wt} \%$ and from 0.06 to $9.24 \mathrm{wt} \%$ respectively (Fig. 11a). It defines a continuous XNa varying from 2.00 to 98.9 mol \% with a higher frequency of high XNa inclusions (63.1 mol \% in average). Contrasted contents in alkalis can be observed in different mica inclusions from a single sample, within the same chromite grain, and even within the same polymineralic inclusion (e.g. 16OM27: two contrasted mica, associated to an amphibole, with $\mathrm{XNa}=7.4$ and 67.8 respectively). The continuous evolution from Na- to K-rich mica is observed in inclusions from all rock types except in pure dunites in which a gap is observed between aspidolite $(\mathrm{XNa}=83.6-98.3 \mathrm{~mol})$ and phlogopite $(\mathrm{XNa}=$ 15.6-37.8 mol \%) (Fig. 11a). The XMg is mainly 87.8-96.8 mol \% (excepting 83.9 mol \% for one analysis). The $\mathrm{TiO}_{2}$ ranges from 0.73 to $6.64 \mathrm{wt} \%$. It is more variable and higher in amphand opx/pl/cpx-bearing dunites than in other dunite types (Fig. 11b). The mica inclusions for which $\mathrm{Cl}$ and $\mathrm{F}$ contents were determined show variations from detection limits to $0.10 \mathrm{wt} \%$ (mean $0.03 \mathrm{wt} \%$ ) and $0.36 \mathrm{wt} \%$ (mean $0.13 \mathrm{wt} \%$ ) respectively.

\section{Olivine}

Olivine inclusions in chromites are forsterite characterized by Fo $(100 \times$ molar $\mathrm{Mg} /(\mathrm{Mg}+$ $\left.\left.\mathrm{Fe}_{\text {total }}\right)\right)=88.6-94.8 \mathrm{~mol} \%, \mathrm{NiO}=0.19-0.50 \mathrm{wt} \%$ and $\mathrm{CaO}=0.01-0.27$ wt \%. Olivine 
inclusions generally overlap with the olivine matrix in terms of $\mathrm{Fo}$ and $\mathrm{NiO}$, with a higher frequency of high values (Fig. 12a). The $\mathrm{CaO}$ content in inclusions is however clearly within the low values variation range displayed by the olivine matrix, except for inclusions in pure dunites that show slightly higher values than dunites containing other interstitial minerals (Electronic supplement 2).

\section{Orthopyroxene}

Orthopyroxene inclusions in chromites are enstatite with $\mathrm{XMg}=87.1-93.5 \mathrm{~mol} \%$ (apart from 1 inclusion with $\mathrm{XMg}=82.1 \mathrm{~mol} \%), \mathrm{Al}_{2} \mathrm{O}_{3}=0.33-4.31$ wt $\%, \mathrm{Cr}_{2} \mathrm{O}_{3}=0.47-1.57$ wt $\%$ and $\mathrm{TiO}_{2}=0.02-0.75 \mathrm{wt} \%$ (Fig. 12b). The variation in $\mathrm{XMg}$ is more variable in amph- and opx/pl/cpx-bearing dunites than in other dunite types; another already evoked feature is that orthopyroxene in inclusion was never observed in pure dunites.

\section{Garnet}

Two types of garnet were analysed: grossular and hydrogrossular according to the calculation of molar proportions (Locock, 2008). The $\mathrm{SiO}_{2}$ content varies between 34.6 and $39.0 \mathrm{wt} \%$ in grossular and between 21.9 to $31.3 \mathrm{wt} \%$ in hydrogrossular. It progressively decreases from grossular to hydrogrossular, with the increasing hydrated character $\left(\mathrm{SiO}_{2}\right.$ vs. sum of oxides, $\mathrm{R}^{2}$ $=0.9452$; Electronic supplement 2). The $\mathrm{TiO}_{2}$ content displays a wide variation range and reaches high values in about the half of the dataset (low-Ti group: $\mathrm{TiO}_{2}=0.01-0.28 \mathrm{wt} \%(\mathrm{n}=$ 16); high-Ti group: $\mathrm{TiO}_{2}=0.84-5.42 \mathrm{wt} \%(\mathrm{n}=11)$; Fig. 12c). When the $\mathrm{TiO}_{2}$ content is high, it concerns all garnet inclusions in a given samples.

Plagioclase

Most of the analysed plagioclase inclusions, identified in 8 samples, are anorthitic. The An 
content $(100 \times$ molar $\mathrm{Ca} /(\mathrm{Ca}+\mathrm{Na}+\mathrm{K}))=86.2-92.0 \mathrm{~mol} \%$, excepting one analysis at $77.0 \mathrm{~mol}$ \%. The An content is lower in inclusions in $\mathrm{pl} / \mathrm{cpx}$-bearing dunites, varying from 77.0 to 88.6 mol \% and reaching $85.5 \mathrm{~mol} \%$ in average $(86.2-88.6 \mathrm{~mol} \%$ without the singular $77.0 \mathrm{~mol} \%$ analysis), than in amph- (89.9-90.6 mol \%) and opx/pl/cpx-bearing dunites (86.7-92.0 mol \%).

\title{
Chemical variability in chromite and silicate inclusions across the DTZ
}

The Figure 13 shows an overview (i.e. all the cross-sections merged in a single one) of the major element variations for the chromite and their amphibole inclusions across the whole Maqsad DTZ. The vertical variations in the composition of other silicate inclusions are described in details, and for each type of dunite, in Electronic Appendix 2.

\begin{abstract}
As a whole, we observe a higher variability of the chemical compositions of both chromite and its hosted inclusions above the altitude of $850 \mathrm{~m}$ (i.e. about 200-250 above the base of the DTZ). It corresponds to the appearance of interstitial orthopyroxene and more generally to a higher amount of interstitial minerals in the higher levels of the Maqsad DTZ (Fig. 6). The main characteristics that may be highlighted along this upper section are the different trends depending on the nature of the host rock, with negatively correlated trends in the composition of inclusions between pure, cpx- and pl/cpx-bearing dunites on one hand, and amph- $( \pm$ opx/pl/cpx) and opx/pl/cpx-bearing dunites on the other hand (Fig. 13). Accordingly, it appears that chromite and amphibole (and other silicates) inclusions have compositions specific to the opx/pl/cpx-bearing dunites lithological type, more and more contrasting with other types of dunites in the higher levels of the DTZ (e.g. buffered XCr values in between 55 and 60 in chromite, decreasing $\mathrm{XMg}$ and increasing $\mathrm{TiO}_{2}$ in both chromite and amphibole, increasing $\mathrm{Na}_{2} \mathrm{O}$ in amphibole, upsection).
\end{abstract}




\section{DISCUSSION}

Relationships between the formation of dunite and the formation of chromitite at the crust-mantle transition

Dunites and chromitites in ophiolites as fluid fluid-melt-rock reaction companion products In ophiolites and present-day oceans, dunites in the mantle section and from the mantle-crust transition zone are mostly interpreted as reactional in origin, replacive after the mantle harzburgites' orthopyroxene dissolution by reacting with interstitial melt (e.g. Dick, 1977; Quick, 1981a, 1981b; Kelemen, 1990; Kelemen et al., 1992, 1995). In the case of the Oman ophiolite and more specifically the Maqsad area, the reactional origin of the DTZ has been strongly evidenced through years, based on field and structural observations (e.g. Ceuleneer and Nicolas, 1985; Rabinowicz et al., 1987; Ceuleneer et al., 1988; Nicolas et al., 1988; Boudier and Nicolas, 1995) and petrology and geochemical signatures (e.g. Godard et al., 2000; Koga et al., 2001; Abily and Ceuleneer, 2013; Rospabé et al., 2017, 2018, 2019a). Among important observations are the alternating mantle harzburgites and dunites at the base of the DTZ showing gradational contacts with the host harzburgite related to the resorption of orthopyroxene along the margins of former melt porous flow channels (Ceuleneer et al., 1996), the systematic presence of a reactional dunitic aureole surrounding chromitites hosted by mantle harzburgites (e.g. Peters \& Kramers, 1974; Augé, 1987; both references concerning massifs in the North of Oman), or the minor and trace element contents in olivine and dunite whole rocks that are much closer from mantle olivine and harzburgites than from cumulates (e.g. Kelemen et al., 1995; Godard et al., 2000; Rospabé et al., 2018). Similarly, ol-rich rocks at the mantle-crust transition in other ophiolites and present-day oceans are regularly classified as 'hybrid' with an olivine matrix mostly mantle-derived and other interstitial minerals (e.g. clinopyroxene, plagioclase) that crystallized from migrating melts (e.g. Takazawa et al., 2007; Drouin et al., 2009; Sanfilippo et al., 2015; Basch et al., 2018; see also Bowen (1915) that 
introduced early the term 'hybrid' to characterize peridotites injected by melts). These are the 'impregnated dunites' which share a common origin with the 'pure dunites', the major difference being the incomplete extraction of interstitial melt before crystallization in response to cooling (Rospabé et al., 2018).

Most minerals in inclusion in the disseminated chromite grains in the DTZ dunites (pargasitic amphibole, clinopyroxene, orthopyroxene, K- and Na-mica, olivine, 'hybrid' diopside for the most abundant; Fig. 5), were previously documented in chromitites from the Maqsad area (Lorand and Ceuleneer, 1989; Leblanc and Ceuleneer, 1991; Schiano et al., 1997; Borisova et al., 2012; Rollinson et al., 2018; Zagrtdenov et al., 2018; Rospabé et al., 2019b). This implies the existence of common petrogenetic processes at the origin of both dunites and chromitites at the mantle-crust transition (Rospabé et al., 2017, 2020). This strong correlation is confirmed on robust statistical grounds in the present work (Figs. 5 and 6).

The same minerals are present in inclusions in chromitites from other contexts: in the massifs from the north-western part of the Oman ophiolite that evolved in a calc-alkaline environment (Augé, 1987; Ahmed and Arai, 2002), in other ophiolites worldwide (e.g. Talkington et al., 1984; Robinson et al., 2015; Johan et al., 2017), as well as in chromitites from continental layered intrusions (e.g. Li et al., 2005; Spandler et al., 2005). However, in spite ophiolitic chromitites/disseminated chromites and chromitites in layered intrusions share some similarities, their very contrasting origins must be kept in mind to avoid shortcuts in transposing processes from a magmatic environment to another. The major difference is that the surrounding dunite is mostly interpreted as a result of melt-peridotite reaction in ophiolites, while it is purely cumulative in layered intrusions (even if chromitites are cumulates in both cases). 
Although the mafic dikes that intruded the mantle section of the Maqsad diapir crystallized from a water-poor MORB (Benoit et al., 1996; Ceuleneer et al., 1996; Python and Ceuleneer, 2003), the widespread occurrence, in the DTZ, of high-Mg orthopyroxene and amphibole both as interstitial phases in dunites or in inclusions in chromite calls for the local presence, at the top of the diapir, of a Si- and volatile-richer melt than MORB. These orthopyroxenes also contrast with the ones from gabbronorites from the calk-alkaline series ultra-depleted in HFSE (e.g. Ti) observed at the border of the Maqsad diapiric structure: the parent melt of these gabbronorites is attributed to the hydrated re-melting of the formerly frozen, hydrothermalized lithospheric mantle with no initial contribution of MORB, mixing with MORB taking place later during the rise of the diapir and formation of the DTZ (Benoit et al., 1999; Clénet et al., 2010). Accordingly, the melt or fluid at the origin of the interstitial mineralogy in DTZ dunites, looking exotic in a MORB context, was not produced by the decompression melting of an asthenospheric diapir and was called 'lithospheric' (Rospabé et al., 2017). It was obviously involved in the formation of the DTZ: hybridized with MORB, it was either the cause or a byproduct of the crystallization of chromite and of the formation of associated dunites.

At first glance, the general overview of the relative frequency of occurrence of each silicate phase in inclusion (Fig. 5c-d), from pure dunites to cpx-bearing, pl/cpx-bearing and amphbearing $( \pm \mathrm{opx} / \mathrm{pl} / \mathrm{cpx})$, then opx/pl/cpx-bearing dunites, highlights (1) the decreasing abundance of mineral phases that can be regarded as belonging to the MORB kindred (ol, pl, cpx), associated to (2) the increasing abundance of the mineral phases (orthopyroxene, amphibole, mica, garnet, diopside) witnessing the $\mathrm{Si}$-, Na- and volatile-richer component that hybridized with the MORB and triggered the formation of dunites and related lithologies in the DTZ, including chromitites (e.g. Johan et al., 1983; Talkington et al., 1984; Spandler et al., 
Our data confirm that both silica-rich melt (i.e. Si-richer than MORB) and water are fundamental parts of the story (i.e. not mutually exclusive), and reveal the role of alkalis evidenced by the presence of phlogopite and aspidolite inclusions. On the other hand, whole rock dunite trace element compositions (e.g. REE) have highlighted the importance of fluidmelt-rock interactions in addition to simpler processes of fractional crystallization and/or incongruent dissolution of orthopyroxene in dry conditions (Rospabé et al., 2018). The strong correlation between the bottom to top chemical evolution patterns across the Maqsad DTZ (both in dunites and chromitites) and the location of syn-accretion normal faults (Rospabé et al., 2019a, 2019b, 2020) supports a hydrothermal origin for the hydrated component, fault planes being avenues for fluids input at different stages of the Oman ophiolite thermal evolution (e.g. Abily et al., 2011; Zihlmann et al., 2018). Thermometric studies have likewise supported the delivery of hydrothermal fluids to the lower oceanic crust and the transition zone beneath oceanic ridges (e.g. VanTongeren 2008; Dygert et al., 2017; Sun and Lissenberg, 2018, EPSL, Canil et al., 2019, Lithos), also supported by petrological and geochemical studies (e.g. Benoit et al., 1999; Bosch et al., 2004; Koepke et al., 2005, 2014; Nonnotte et al., 2005). The involvement of a water-rich melt or fluid fraction at high, magmatic temperatures potentially initiated or enhanced the mantle harzburgite dunitization - and thus the release of Si (and, in 
lesser extent, Cr, Al, Ti, Na; e.g. Quick, 1981b) following orthopyroxene dissolution - though fluid-melt-peridotite reactions (Rospabé et al., 2017).

\section{Mantle harzburgite dunitization as a potential source of $\mathrm{Cr}$}

The concept of dunitization was introduced to describe the transformation of mantle harzburgites into dunites through the incongruent dissolution of orthopyroxene in reaction to the percolation of a melt that was saturated in opx when it formed at depth in the mantle and became undersaturated in this mineral at lower pressure (e.g. Dick, 1977; Quick, 1981a, 1981b; Kelemen, 1990; Kelemen et al., 1992, 1995). Orthopyroxene contains Cr as minor content (about 0.5 to $1 \mathrm{wt} \%$ in Oman, e.g. Monnier et al., 2006; ${ }^{\text {opx } / \text { liq }} D_{\mathrm{Cr}}=1.9$, Bédard et al., 1994) and its dissolution will contribute to feed newly formed chromite grains, as the solubility of $\mathrm{Cr}$ in silicate melts is quite low and the amount of $\mathrm{Cr}$ that can be accommodated in newly formed olivine is moderate (Abily and Ceuleneer, 2013) ( ${ }^{\mathrm{o} / / \mathrm{liq}} D_{\mathrm{Cr}}=0.6$, Bédard et al., 1994). A similar process, while in a different environment, has been proposed with the assimilation of peridotites and incongruent dissolution of their pyroxenes to form high $\mathrm{XCr}$ chromitites at the contact with surrounding mafic rocks in the Bay of Islands ophiolite (Bédard and Hébert, 1998). Even if the volume of chromite (in both ore bodies and scattered in the dunite) is more important in the DTZ than elsewhere, it represents globally a very weak percentage of the DTZ itself. On the other hand, the volume of mantle harzburgite available for the reaction is virtually infinite. Although to quantify this would be hazardous, it is possible that the amount of chromium liberated by the dissolution of pyroxene highly contribute to the formation ore bodies and scattered chromites.

On the other hand, it was suggested that dunite channels cropping out in the Oman ophiolite mantle section contain chromites with a very contrasting composition (e.g. significantly higher 
$\mathrm{TiO}_{2}$ content), in addition to a different texture, than the Cr-spinels in nearby surrounding mantle harzburgites, which is an argument for the role of dunite channels in the extraction of MORB from the upper mantle to the crust (Kelemen et al., 1995). The same contrast has been observed for the Maqsad DTZ dunites (Koga et al., 2001; Abily and Ceuleneer, 2013). A reasonable hypothesis is that the mantle harzburgite dunitization is, in addition to orthopyroxene dissolution, also accompanied by the dissolution/reprecipitation of the residual Cr-spinel (i.e. residual Cr-spinel dissolution, 'magmatic' chromite re-precipitation). This is consistent with the presence, although much less frequent than in the disseminated chromites, of a few amphibole and mica in inclusion in $\mathrm{Cr}$-spinels in the harzburgites alternating with dunites at the base of the DTZ. They can represent the incipient stage of the dunitization process, frozen at the time the igneous activity of the Maqsad diapir stopped, while the much higher inclusions content in chromites in the DTZ dunites supports their re-precipitation. The lower $\mathrm{TiO}_{2}$ content of the inclusions in $\mathrm{Cr}$-spinels in harzburgites than in chromites in dunites (Figs. 8, 9, 11, 12b; e.g. up to $5 \mathrm{wt} \%$ in amphibole) attests on the other hand of the less evolved character of the hybrid melt that triggered or enhanced the dunitization during this incipient stage of transformation of harzburgite into dunite recorded at this depth. (Rospabé et al., 2017, 2018). In this frame, an 'infinite' source of $\mathrm{Cr}$ for the formation of chromitite ore bodies, especially within the DTZ and within the uppermost mantle beneath oceanic spreading centres, may be provided by the dunitization itself with the dissolution of both residual Cr-spinel and pyroxenes and crystallization of a new generation of chromite grains entrapping minerals issued from the reactant hybrid melt.

\section{Chromite-hosted silicate inclusions record from high temperature, magmatic events to metamorphic to low temperature, alteration processes}

The high diversity in the silicate inclusions content in the Maqsad DTZ disseminated chromites 
partly reflects the very large temperature range in which they formed, from magmatic crystallization products to later metamorphism and lower temperature alteration. Olivine, orthopyroxene, clinopyroxene, amphibole, mica and plagioclase have compositions consistent with an igneous origin. About $40 \%$ of the studied samples are pure dunites, i.e. devoid of any interstitial minerals between olivine grains excepting chromite. These pure dunites, similar to impregnated dunites, also contain a large cargo of inclusions (mostly amphibole and clinopyroxene; Fig. 5b) in their scattered chromite grains. Consequently, inclusions cannot have formed after the formation of chromite by sintering and entrapment of surrounding minerals, or by the migration of melt that would have been trapped in already formed chromite but not in the matrix (Rospabé et al., 2020). It is thus likely that the inclusions-forming minerals nucleated just before the host chromites (e.g. microcrystals in the parent melt) or co-precipitated together with the chromites from the same parent melt.

The crystallization temperatures can be roughly estimated, although a more precise determination would require experimental data in chemical systems under (possibly out of equilibrium) conditions that remain poorly or not explored up to now. At first glance, it could be supposed that orthopyroxene, pargasite and phlogopite-aspidolite micas crystallized or precipitated from a melt or fluid at temperature ranging from $1050^{\circ} \mathrm{C}$ down to $600^{\circ} \mathrm{C}$ as stressed by Borisova et al. (2012) in the Maqsad DTZ chromitites case (i.e. $600-950^{\circ} \mathrm{C}$ for mica, 600 $1050^{\circ} \mathrm{C}$ for enstatite and pargasite, $950-1050^{\circ} \mathrm{C}$ for host chromite). This is the temperature stability range for pargasitic amphibole in the presence of $\mathrm{H}_{2} \mathrm{O}$ (e.g. Boyd, 1959; Feig et al., 2006; Presnall, 2013). Phlogopite is not stable at temperatures higher than $1000^{\circ} \mathrm{C}$ while a miscibility gap exists in the phlogopite-aspidolite solid solution at $2 \mathrm{kbar}$ and $700^{\circ} \mathrm{C}(\mathrm{Costa}$ et al., 2001). The existence of a compositional gap observed in mica inclusions in the Maqsad chromitites (Borisova et al., 2012), with the clear dichotomy between the phlogopite and 
aspidolite end-members, is not observed in the case of the disseminated chromites (Fig. 11). This might be an artefact related to the lower amount of samples analysed before our survey or, if real, could reflect a higher equilibration temperature for the mica inclusions in the disseminated chromites than in the chromitites (Borisova et al., 2012; Arai and Miura, 2016; see also Costa et al., 2001). Furthermore, the high $\mathrm{TiO}_{2}$ content in amphibole, mica and in a lesser extent orthopyroxene (Figs. 8, 11 and 12) may have increase their thermal stability field (Augé, 1987 and references therein) to temperatures similar to the ones at which their host chromite and possibly other clinopyroxene and very scarce plagioclase inclusions crystallized. The effect of subsolidus re-equilibration between the inclusions, host chromites and surrounding minerals of the dunites is not investigated here. However, chemical major element profiles have been performed in samples from a neighbouring stratiform chromitite showing a wide range of chromite modal content (Rospabé et al., 2019b). At the thin section scale, we have shown that $\mathrm{Mg}, \mathrm{Fe}, \mathrm{Cr}$ and $\mathrm{Al}$ vary according to the chromite/olivine ratio but that $\mathrm{TiO}_{2}$ variations in chromite are totally independent from the modal composition. We thus conclude that the higher $\mathrm{TiO}_{2}$ content common to all minerals independently from their habitus in amphbearing and opx/pl/cpx-bearing dunites better supports a more evolved parent melt for all the inclusions, chromites and interstitial minerals in these samples.

One possible explanation would be that the parent melts of interstitial clinopyroxene and plagioclase are primitive MORB issued from the partial melting of the Maqsad diapir, not or poorly contaminated by the hydrous, lithospheric component. On the other hand, orthopyroxene and amphibole crystallized from a more evolved, $\mathrm{Si}$ - and water-rich melt or fluid. Orthopyroxene and amphibole have likewise been reported (1) along ol, pl and cpx grain boundaries in gabbros from the lower oceanic crust (Koepke et al., 2005, 2014), and (2) as globular inclusions, in association with phlogopite and aspidolite, in olivine and plagioclase in 
the Murotomisaki Gabbroic Intrusion (MGI, Japan) - chromite also occurs as inclusion in ol and $\mathrm{pl}$ in these rocks (Hoshide and Obata, 2009, 2012). It has been proposed that the infiltration of a fluid fraction along grain boundaries in mafic rocks may trigger the hydrated partial melting of the primary minerals, with the concomitant crystallization of both amphibole and orthopyroxene (e.g. Koepke et al., 2005). Experiments have shown that the hydrated partial melting of mafic rocks produces a trondhjemitic melt (Berndt et al., 2005; Wolff et al., 2013). In this frame, the Si- and water-rich melt or fluid fraction involved in the formation of the exotic silicate inclusions in chromite in the studied DTZ dunites may derive from the hydrated partial melting of mafic lithologies at the base of the crust and/or from the mantle harzburgite orthopyroxene dissolution itself (Rospabé et al., 2017), the hydrated component being issued from the deep introduction of hydrothermal fluids accounted for by the early development of synmagmatic faults (Abily et al., 2011; Rospabé et al., 2019a, 2019b, 2020).

The presence of nepheline, similar to that enclosed in the DTZ disseminated chromites, together with jadeite and albitic feldspar was reported in other ophiolites (e.g. Johan and Le Bel, 1978; Legendre, 1982; Johan et al., 1983, 2017; Talkington et al., 1984; Plissart et al., 2017) as well as in a chromitite associated to abyssal peridotites as reported by Matsukage and Arai (1998). These latter have interpreted nepheline and albite as two associated magmatic products, albite precipitating first followed by the eutectic crystallization of both phases $\left(1100-1200{ }^{\circ} \mathrm{C}\right)$, and finally jadeite as the subsolidus reaction of albite and nepheline at low temperatures (250-300 ${ }^{\circ} \mathrm{C}$ ) at slightly less than 3 kbar. In the present study, nepheline and jadeite occur as monomineralic inclusions or in polymineralic inclusions in association with amphibole (Fig. 4e-f), clinopyroxene or mica. They can be reasonably interpreted as crystallization products from similar melts. In this frame, jadeite might result from the destabilization of nepheline during cooling. Alternatively, nepheline could result from the destabilization of pargasite into 
the assemblage diopside + forsterite + nepheline + spinel + anorthite + vapor, at temperature higher than $1050{ }^{\circ} \mathrm{C}$ (Boyd, 1959; see also Holloway, 1973 and Augé, 1987).

The origin of the diopside, grossular garnet and pectolite inclusions is typically controversial as they are classically interpreted as low temperature alteration products in abyssal and ophiolitic materials: this assemblage chiefly replaces the primary minerals during the rodingitization ( $\mathrm{Ca}$ enrichment, $\mathrm{Si}$ loss) of mafic or leucocratic rocks, related to the serpentinization of the surrounding ultramafic rocks or more generally to hydrothermal circulations in temperature conditions of about $300-350{ }^{\circ} \mathrm{C}$ (e.g. Schandl et al., 1989; Esteban et al., 2003; Austrheim and Prestvik, 2008; Frost et al., 2008; Bach and Klein, 2009; Ghosh and Morishita, 2011; Akizawa et al., 2016). Following this hypothesis of a secondary origin, diopside and grossular should represent alteration products after clinopyroxene and plagioclase respectively in the studied samples. However, this is unlikely in the case of the Maqsad disseminated chromites: the two relative frequency histograms in Figure 5c-d show that the increasing amount of 'exotic' phases (amph, mica, opx + diopside and garnet inclusions) is associated to the decrease in the occurrence of the assemblage ol-cpx-pl in inclusion from pure dunite to impregnated dunites containing more and more interstitial minerals witnessing a hydrous parent melt. This is observed even when diopside and garnet are taken into account (Fig. 5d), while this correlation should not exist if these two minerals were essentially of secondary origin. This is especially true regarding diopside: it constitutes the third most frequent silicate in inclusion (Fig. 5a), and its frequency of occurrence is not related to the one of the igneous clinopyroxene (Fig. 5b). In addition, diopside in inclusions have compositions spanning between the 'magmatic' compositions of clinopyroxene impregnations and the 'hydrothermal' compositions of diopside from diopsidites that formed at $600-800{ }^{\circ} \mathrm{C}$ following high temperature hydrothermal events (see Python et al., 2007, 2011 for more details). On the 
other hand, the high $\mathrm{TiO}_{2}$ content in some grossular (up to $5 \mathrm{wt} \%$ ) cannot result from the alteration of plagioclase \pm chromite, and the existence of a Ti-rich alteration fluid is unlikely. Consequently, we suggest that both diopside and grossular garnet formed at lower temperature than the cpx-opx-mica-amph assemblages, and/or witness the greater proportion of the hydrated component (relative to MORB) in the hybrid melt involved in the DTZ genesis (Rospabé et al., 2017).

Apatite is a more unusual phase among the inclusions in the Oman ophiolite chromites (Rollinson et al., 2018). Experimental works have shown that apatite appears in crystallization sequences from late-stage, highly evolved MORB (Koepke et al., 2018). Cl-rich apatite (up to $3.06 \mathrm{wt} \% \mathrm{Cl}$ ) described in cumulates from present-day oceanic crust has been interpreted as the product of degassing during fractional crystallization, or by the assimilation of a seawaterderived component by the crystallizing mush (Meurer and Natland, 2001). The single chlorapatite observed in inclusion may reasonably represent an additional primary witness of the hybrid Si- and $\mathrm{H}_{2} \mathrm{O}$-rich melt or fluid (e.g. Morishita et al., 2003) involved in the formation of both dunite and chromitite (Rospabé et al., 2017). It could result from a magmatic to metamorphic process involving a high temperature seawater-derived hydrothermal fluid (high $\mathrm{Cl}$ content) in a cooling context leading to the cessation of the magmatic activity (Rospabé et al., 2020). Although the $\mathrm{Cl}$ and $\mathrm{F}$ contents in amphibole and mica inclusions studied here are lower than in other examples of layered intrusions (e.g. Boudreau et al., 1986; Mathez and Webster, 2005), the highest values are observed in amphibole approaching the synmagmatic faults (Rospabé et al. 2020), and in mica exactly at the elevation where chlorapatite occurs (Electronic Appendix 2 and Fig. 6). Accordingly, this suggests that Cl-rich fluids, potentially seawater-derived, are involved from early stage, at magmatic temperatures, to lower temperatures (see also Arai et al., 2020). In this frame, the consumption of $\mathrm{OH}$ relative to $\mathrm{Cl}$ 
by the crystallization of phlogopite and/or the percolation of chromatographically exotic fluid/melt through the freezing dunitic mush may also have originate the appearance of apatite here, mineralogically similar to what was described in layered intrusions (Mathez and Webster, 2005).

The origin of pectolite in inclusion in the disseminated chromites (sample 15OM110B) is more puzzling. It is usually seen as a replacement mineral or as a phase filling the porosity in rodingitized rocks. Its association with amphibole and its very low $\mathrm{MgO}$ content cannot be accounted easily for by the replacement of one of the other silicates identified as inclusion, except plagioclase (not observed in this sample) or more probably grossular. The solely report of pectolite in Oman is in a rodingite (fully altered plagiogranites or diopsidite) from the periphery of the Maqsad area, where it fills veins and mineral rims (Mombru, 2015).

As the result of the progressive cooling of the Maqsad DTZ following the cessation of the magmatic activity, the (undoubtedly) low temperature alteration event (i.e. serpentinization) affected both the dunitic matrix and the silicate inclusions in the disseminated chromites. In those, low temperature process is evidenced by the alteration rims at the contact between the inclusions and their host chromite (mostly serpentine, chlorite and tremolite, more rarely carbonates, magnetite and sulphides). Consequently, the chromite-hosted silicate inclusions from the DTZ recorded processes that occurred on a wide range of temperatures, from high temperature, magmatism to metamorphism toward lower temperature alteration conditions.

\section{The chicken and egg dilemma linking dunites and chromitites}

The competition between orthopyroxene and chromite crystallization

Our exhaustive survey allowed us to establish that the distribution of the nature and composition 
of the included minerals is not random across the Maqsad DTZ (Figs. 5 and 6). It shows an increasing abundance, upsection, of the silicates witnessing the silica-rich (opx) and hydrated and alkali-rich (amph, mica) nature of their parent melts, inconsistent with crystallization of a common MORB. This evolution mirrors the one of the interstitial silicates in the olivine matrix, particularly marked by the much higher frequency of orthopyroxene above the altitude of 850 m (i.e. about 200-250 above the base of the DTZ) together with the higher amount of inclusions of mica (Fig. 6). Interestingly, (1) this correlation holds for the presence of each interstitial mineral phase whatever their apparent modal abundance in the host dunite, and (2) these levels correspond precisely to the altitude of the main chromitite occurrences in this area. Accordingly, the contrasted assemblages of silicate inclusions depend only on the instantaneous composition of their parent melt (+/- fluid) and less on the variable physical conditions that led to their nucleation and growth.

The dichotomy between the opx/pl/cpx-bearing dunites \pm chromite (including orthopyroxene inclusion) on one hand, and the chromitites \pm minor orthopyroxene (interstitially and in inclusion) on the other hand elegantly illustrates the local competition between the crystallization of orthopyroxene and the concentration of chromite, differently distributed within the same levels. This probably reflects the crossing of the chromite-orthopyroxene cotectic, supporting the preferential fractionation of one of both phases depending on the more or less important contribution of the evolved $\mathrm{Si}$-, $\mathrm{Na}$ - and volatile-rich melt fraction relative to the MORB in the hybrid parent melt (e.g. Irvine, 1975, 1977a, 1977b).

Experimental works have shown that an addition of water will shift the phase relations crystallizing from tholeiitic or noritic liquids (e.g. Feig et al., 2010; Mathez and Kinzler, 2017), basically with a shift from the assemblage $\mathrm{pl}+\mathrm{opx}+\mathrm{cpx}$, to $\mathrm{pl}+\mathrm{opx}$, to $\mathrm{pl} \pm \mathrm{ol}$, to chromite $\pm \mathrm{ol}$ 


\section{The cycle of dunites-chromitites formation}

The observations reported above led us to formulate three end-membered working hypotheses for the links between the DTZ dunites and chromitites:

\section{(1) The prior formation of dunite triggers the subsequent formation of chromitite:}

Chromitites formed following a widespread process first. Dunites form at the expense of residual mantle harzburgites following fluid-melt-rock reactions. The dissolution of the residual pyroxenes (mostly orthopyroxene) and Cr-spinel releases a relatively high amount of $\mathrm{Cr}$. Interstitial impregnations in dunites, comprising disseminated chromites, crystallize at different places along the DTZ. The residual melts, saturated in $\mathrm{Cr}$, are extracted and hybridized along fault zones where they will massively crystallize to form chromitite ore bodies (Boudier and Al-Rajhi, 2014; Zagrtdenov et al., 2018). In this scenario the fault zones are also the media for the continuous hydrothermal, seawater-derived fluids (potentially supercritical) introduction down to the DTZ (e.g. higher $\mathrm{Cl}$ content in amphibole approaching fault zones; Rospabé et al., 
2020). In this hypothesis, the chromitite cannot form without the prior mantle harzburgite dunitization, making the dunite formation the chicken at the origin of the existence of the chromitites, the eggs.

The analysis of both the chromite and the enclosed silicate inclusions shows a systematic decoupling between the compositions in pure and cpx-bearing dunites on one hand, and the ones in amph- to opx/pl/cpx-bearing dunites (e.g. higher $\mathrm{XCr}$ in chromite, higher $\mathrm{TiO}_{2}$ in chromite and inclusions) on the other hand. These lithologies represent two end-members in the chemical variation ranges we observed, likely deriving from the primitive MORB (clinopyroxene, plagioclase) and from the lithospheric evolved melt (orthopyroxene, amphibole). With a few exceptions, the composition of chromite and associated silicate inclusions in the DTZ chromitites are very frequently close to the one in $\mathrm{pl} / \mathrm{cpx}$-bearing dunites, thus intermediate between the two other contrasted main trends (Figs. 7 and 8). This may represent the perfect condition to fractionate only chromite from the melt hosting $\mathrm{Cr}$, itself being a mixture between residual fluid-melt fractions issued from the two end-members, mostly in the vicinity of syn-magmatic, syn-hydrothermal faults (e.g. Fo and XMg buffered to high values both in olivine and chromite, potentially related to a higher oxygen fugacity with the higher amount of water; Feig et al., 2006).

(2) The prior formation of chromitite triggers the subsequent formation of dunite:

Chromitites formed in response to a localized process first. The hybridization between the MORB and the evolved $\mathrm{Si}_{-}, \mathrm{Na}-$ and volatile-rich melt or fluid occurs within or along discontinuities (e.g. magmatic breccias developed by melt and/or fluid influxes along a fault zone reaching an unconsolidated mush; Rospabé et al., 2019a, 2019b, 2020). Chromite massively precipitates within or in the direct vicinity of the hybridization area leading to the 


\section{(3) Both dunite and chromitite form simultaneously:}

An intermediate hypothesis is to consider contemporaneous widespread and localized processes, assuming that one lithology did not form in response to the formation of the other at the scale of the whole mantle-crust transition zone, but that both dunites (and their disseminated chromites and other impregnations) and chromitites formed at the same time along the DTZ. This model calls for spatial variations in the involvement and contribution of the MORB and of the hybrid melt (i.e. spatial rather than temporal variations), as well as of the spatial development of the fault zones. In other words, both dunites and chromitites can each be the chicken/egg of the other, according to the local chemical, physical and thermal conditions at a given place within the DTZ.

To revolve these main hypotheses, the three assumptions are finally right in a way depending on the time and spatial scale at which the processes occur. Chromitites in ophiolites cannot form without the prior mantle harzburgite dunitization (the dissolution of opx and $\mathrm{Cr}$-spinel contributing to the source of $\mathrm{Cr}$ in addition to the $\mathrm{Cr}$ transported in MORB), but also seem to be deeply linked to the formation of the more exotic amph- and opx/pl/cpx-bearing dunites. 
This defines a cycle which can restart at each step of the mantle dunitization process at the top of the mantle diapir, which also depends on the extent of hybridization between the MORB and the evolved $\mathrm{Si}$-, Na- and volatile-rich lithospheric melts. This is in agreement with the cyclic nature of the melt delivery and of the tectonic-hydrothermal activity beneath oceanic spreading centres.

\section{CONCLUSION}

The genesis of chromitites, at least in the context of ophiolites, is usually addressed by the study of the most remarkable ore bodies. In the present study, we adopted a different approach by extensively surveying the chromite-hosted silicate inclusions in disseminated chromites in dunites hosting the ore bodies. They are among the products of the fluid-melt-peridotite reaction that led to the development of the dunitic mantle-crust transition zone. Our results suggest that the ore genesis processes involved in the formation of chromitites are not restricted to the ore bodies themselves but operated on the much larger scale, the one of the whole DTZ. It leads to consider the entire DTZ as an ore deposit. In this spirit, the DTZ dunites may be regarded as a low-grade dispersed ore. The hybrid Si-, Na- and volatile-rich fluids or melts involved in the formation of both dunites and chromitites are issued from the interaction between the hot uprising Maqsad diapir (producing MORB more or less continuously), and the colder, hydrothermally altered, previously crystallized, and potentially re-melting lithospheric lid. In this frame, the mixing between the different fluid or melt fractions is clearly related to the synmagmatic tectonic. To conclude, the DTZ can be viewed as a contact metamorphic aureole between asthenospheric diapirs and hydrated lithospheric lids, and its formation beneath oceanic spreading centres has undoubtedly a major impact on the global geochemical cycles.

\section{ACKNOWLEDGMENTS}


We would like to thank N. Dygert, E. Mathez and an anonymous reviewer for their thorough reviews and comments which helped to improve the quality of the manuscript, as well as A. Kent and G. Zellmer for editorial handling. We greatly thank F. de Parseval, M. Bonnefoy, J.F. Ména and L. Menjot for thin sections manufacturing, and S. Gouy, J. Langlade and Ph. de Parseval for setting the electron microprobes for microprobe data acquisition. We are grateful to M. Al Araimi, M. Al Batashi, A. Al-Rajhi, S. Almusharrafi and other colleagues from the Ministry of Commerce and Industry, Sultanate of Oman, as well as to H. Al Azri, for their longtime hospitality. This work has benefited from a financial support provided by the Centre National de la Recherche Scientifique-Institut National des Sciences de 1'Univers (CNRSINSU) and by the Japan Agency for Marine-Earth Science and Technology (JAMSTEC).

\section{REFERENCES}

Abily, B. \& Ceuleneer, G. (2013). The dunitic mantle-crust transition zone in the Oman ophiolite: Residue of melt-rock interaction, cumulates from high-MgO melts, or both? Geology 41, 67-70.

Abily, B., Ceuleneer, G. \& Launeau, P. (2011). Synmagmatic normal faulting in the lower oceanic crust: Evidence from the Oman ophiolite. Geology 39, 391-394.

Ahmed, A. \& Arai, S. (2002). Unexpectedly high-PGE chromitite from the deeper mantle section of the northern Oman ophiolite and its tectonic implications. Contributions to Mineralogy and Petrology. Springer-Verlag 143, 263-278.

Akizawa, N. \& Arai, S. (2009). Petrologic profile of peridotite layers under a possible Moho in the northern Oman ophiolite: An example from Wadi Fizh. Journal of Mineralogical and Petrological Sciences 104, 389-394.

Akizawa, N., Tamura, A., Fukushi, K., Yamamoto, J., Mizukami, T., Python, M. \& Arai, S. (2016). High-temperature hydrothermal activities around suboceanic Moho: An example 
from diopsidite and anorthosite in Wadi Fizh, Oman ophiolite. Lithos 263, 66-87.

Allan, J. \& Dick, H. B. (1996). Cr-rich spinel as a tracer for melt migration and melt-wall rock interaction in the mantle: Hess Deep, Leg 147. Proceedings of the Ocean Drilling Program: Scientific Results 147, 157-172.

Amri, I., Benoit, M. \& Ceuleneer, G. (1996). Tectonic setting for the genesis of oceanic plagiogranites: evidence from a paleo-spreading structure in the Oman ophiolite. Earth and Planetary Science Letters 139, 177-194.

Arai, S. \& Matsukage, K. (1998). Petrology of a chromitite micropod from Hess Deep, equatorial Pacific: a comparison between abyssal and alpine-type podiform chromitites. Lithos 43, 1-14.

Arai, S. \& Miura, M. (2016). Formation and modification of chromitites in the mantle. Lithos 264, 277-295.

Arai, S. \& Yurimoto, H. (1994). Podiform chromitites of the Tari-Misaka ultramafic complex, southwestern Japan, as mantle-melt interaction products. Economic Geology 89, 12791288.

Arai, S., Miura, M., Tamura, A., Akizawa, N. \& Ishikawa, A. (2020). Hydrothermal Chromitites from the Oman Ophiolite: The Role of Water in Chromitite Genesis. Minerals 10, 217.

Augé, T. (1986). Platinum-group-mineral inclusions in chromitites from the Oman ophiolite. Bulletin de minéralogie 109, 301-304.

Augé, T. (1987). Chromite deposits in the northern Oman ophiolite: Mineralogical constraints. Mineralium Deposita. Springer-Verlag 22, 1-10.

Austrheim, H. \& Prestvik, T. (2008). Rodingitization and hydration of the oceanic lithosphere as developed in the Leka ophiolite, north-central Norway. Lithos 104, 177-198.

Bach, W. \& Klein, F. (2009). The petrology of seafloor rodingites: Insights from geochemical 
reaction path modeling. Lithos 112, 103-117.

Ballhaus, C. G. \& Stumpfl, E. F. (1986). Sulfide and platinum mineralization in the Merensky Reef: evidence from hydrous silicates and fluid inclusions. Contributions to Mineralogy and Petrology 94, 193-204.

Basch, V., Rampone, E., Crispini, L., Ferrando, C., Ildefonse, B. \& Godard, M. (2018). From mantle peridotites to hybrid troctolites: Textural and chemical evolution during melt-rock interaction history (Mt. Maggiore, Corsica, France). Lithos 323, 4-23.

Bédard, J. H. (1994). A procedure for calculating the equilibrium distribution of trace elements among the minerals of cumulate rocks, and the concentration of trace elements in the coexisting liquids. Chemical Geology 118(1-4), 143-153.

Bédard, J. H. \& Hébert, R. (1998). Formation of chromitites by assimilation of crustal pyroxenites and gabbros into peridotitic intrusions: North Arm Mountain massif, Bay of Islands ophiolite, Newfoundland, Canada. Journal of Geophysical Research: Solid Earth 103, 5165-5184.

Benn, K., Nicolas, A. \& Reuber, I. (1988). Mantle-crust transition zone and origin of wehrlitic magmas: Evidence from the Oman ophiolite. Tectonophysics 151, 75-85.

Benoit, M., Ceuleneer, G. \& Polvé, M. (1999). The remelting of hydrothermally altered peridotite at mid-ocean ridges by intruding mantle diapirs. Nature 402, 514-518.

Benoit, M., Polvé, M. \& Ceuleneer, G. (1996). Trace element and isotopic characterization of mafic cumulates in a fossil mantle diapir (Oman ophiolite). Chemical Geology 134, 199214.

Berndt, J., Koepke, J. \& Holtz, F. (2005). An experimental investigation of the influence of water and oxygen fugacity on differentiation of MORB at $200 \mathrm{MPa}$. Journal of Petrology 46, $135-167$.

Borisova, A. Y., Ceuleneer, G., Kamenetsky, V. S., Arai, S., Béjina, F., Abily, B., Bindeman, 
I. N., Polvé, M., De Parseval, P., Aigouy, T. \& Pokrovski, G. S. (2012). A new view on the petrogenesis of the Oman ophiolite chromitites from microanalyses of chromite-hosted inclusions. Journal of Petrology 53, 2411-2440.

Bosch, D., Jamais, M., Boudier, F., Nicolas, A., Dautria, J. M. \& Agrinier, P. (2004). Deep and high-temperature hydrothermal circulation in the Oman ophiolite-petrological and isotopic evidence. Journal of Petrology 45, 1181-1208.

Boudier, F. \& Al-Rajhi, A. (2014). Structural control on chromitite deposits in ophiolites: the Oman case. Geological Society, London, Special Publications 392, 263-277.

Boudier, F., Bouchez, J. L., Nicolas, A., Cannat, M., Ceuleneer, G., Misseri, M. \& Montigny, R. (1985). Kinematics of oceanic thrusting in the Oman ophiolite: model of plate convergence. Earth and Planetary Science Letters 75, 215-222.

Boudier, F. \& Nicolas, A. (1995). Nature of the moho transition zone in the Oman ophiolite. Journal of Petrology 36, 777-796.

Boudreau, A. E., Mathez, E. A. \& McCallum, I. S. (1986). Halogen geochemistry of the Stillwater and Bushveld Complexes: evidence for transport of the platinum-group elements by Cl-rich fluids. Journal of Petrology 27, 967-986.

Bowen, N. L. (1915). The later stages of the evolution of the igneous rocks. The Journal of Geology 23, 1-91.

Bowen, N. L. (1927). The origin of ultrabasic and related rocks. American Journal of Science 80, 89-108.

Boyd, F. R. (1959). Hydrothermal investigations of amphiboles. Researches in geochemistry $377-396$.

Cannat, M., Bideau, D. \& Hébert, R. (1990). Plastic deformation and magmatic impregnation in serpentinized ultramafic rocks from the Garrett transform fault (East Pacific Rise). Earth and Planetary Science Letters 101, 216-232. 
Cassard, D., Nicolas, A., Rabinowicz, M., Moutte, J., Leblanc, M. \& Prinzhofer, A. (1981). Structural classification of chromite pods in southern New Caledonia. Economic Geology 76, 805-831.

Ceuleneer, G. (1991). Evidence for a Paleo-Spreading Center in the Oman Ophiolite: Mantle Structures in the Maqsad Area. Springer Netherlands, 147-173.

Ceuleneer, G. \& Le Sueur, E. (2008). The Trinity ophiolite (California): the strange association of fertile mantle peridotite with ultra-depleted crustal cumulates. Bulletin de la Société Géologique de France 179, 503-518.

Ceuleneer, G., Monnereau, M. \& Amri, I. (1996). Thermal structure of a fossil mantle diapir inferred from the distribution of mafic cumulates. Nature 379, 149-153.

Ceuleneer, G. \& Nicolas, A. (1985). Structures in podiform chromite from the Maqsad district (Sumail ophiolite, Oman). Mineralium Deposita 20, 177-184.

Ceuleneer, G., Nicolas, A. \& Boudier, F. (1988). Mantle flow pattern at an oceanic spreading centre: the Oman peridotite record. Tectonophysics 151, 1-26.

Ceuleneer, G. \& Rabinowicz, M. (1992). Mantle flow and melt migration beneath oceanic ridges: models derived from ob- servation in ophiolites, in mantle flow and melt generation at mid-ocean ridges. In: Morgan, J. P., Blackman, D. B. and Sinton, J. M. (eds) Mantle Flow and Melt Generation at Mid-Ocean Ridges. American Geophysical Union, Geophysical Monograph Series 71, 123-154.

Clénet, H., Ceuleneer, G., Pinet, P., Abily, B., Daydou, Y., Harris, E., Amri, I. \& Dantas, C. (2010). Thick sections of layered ultramafic cumulates in the Oman ophiolite revealed by an airborne hyperspectral survey: Petrogenesis and relationship to mantle diapirism. Lithos 114, 265-281.

Costa, F., Dungan, M. A. \& Singer, B. S. (2001). Magmatic Na-rich phlogopite in a suite of gabbroic crustal xenoliths from Volcán San Pedro, Chilean Andes: Evidence for a solvus 
relation between phlogopite and aspidolite. American Mineralogist 86, 29-35.

Dick, H. J. B. (1977). Partial Melting in the Josephine Peridotite: I, The Effect on Mineral Composition and Its Consequence for Geobarometry and Geothermometry. American Journal of Science 277, 801-832.

Dijkstra, A. H., Barth, M. G., Drury, M. R., Mason, P. R., \& Vissers, R. L. (2003). Diffuse porous melt flow and melt - rock reaction in the mantle lithosphere at a slow - spreading ridge: A structural petrology and LA - ICP - MS study of the Othris Peridotite Massif (Greece). Geochemistry, Geophysics, Geosystems 4.

Drouin, M., Godard, M., Ildefonse, B., Bruguier, O. \& Garrido, C. J. (2009). Geochemical and petrographic evidence for magmatic impregnation in the oceanic lithosphere at Atlantis Massif, Mid-Atlantic Ridge (IODP Hole U1309D, 30 N). Chemical Geology 264, 71-88.

Dygert, N., Kelemen, P. B. \& Liang, Y. (2017). Spatial variations in cooling rate in the mantle section of the Samail ophiolite in Oman: Implications for formation of lithosphere at midocean ridges. Earth and Planetary Science Letters 465, 134-144.

Dygert, N., Liang, Y. \& Kelemen, P. B. (2016). Formation of plagioclase lherzolite and associated dunite-harzburgite-lherzolite sequences by multiple episodes of melt percolation and melt-rock reaction: an example from the Trinity Ophiolite, California, USA. Journal of Petrology, 57, 815-838.

Esteban, J. J., Cuevas, J., Tubía, J. M. \& Yusta, I. (2003). Xonotlite in rodingite assemblages from the Ronda peridotites, Betic Cordilleras, Southern Spain. Canadian Mineralogist 41, $161-170$.

Feig, S. T., Koepke, J. \& Snow, J. E. (2010). Effect of oxygen fugacity and water on phase equilibria of a hydrous tholeiitic basalt. Contributions to Mineralogy and Petrology 160, $551-568$.

Feig, S. T., Koepke, J. \& Snow, J. E. (2006). Effect of water on tholeiitic basalt phase equilibria: 
An experimental study under oxidizing conditions. Contributions to Mineralogy and Petrology 152, 611-638.

Fisher, L. W. (1929). Origin of chromite deposits. Economic Geology 24, 691-721.

Friedrich, B. M., Marques, J. C., Olivo, G. R., Frantz, J. C., Joy, B. \& Queiroz, W. J. A. (2019). Petrogenesis of the massive chromitite layer from the Jacurici Complex, Brazil: evidence from inclusions in chromite. Mineralium Deposita 55, 1105-1026.

Frost, B. R., Beard, J. S., Mccaig, A. \& Condliffe, E. (2008). The formation of micro-rodingites from IODP hole U1309D: Key to understanding the process of serpentinization. Journal of Petrology 49, 1579-1588.

Gerbert-Gaillard, L. (2002). Caractérisation Géochimique des Péridotites de l'ophiolite d'Oman: Processus Magmatiques aux Limites Lithosphère/Asthénosphère. Université Montpellier II.

Ghosh, B. \& Morishita, T. (2011). Andradite-uvarovite solid solution from hydrothermally altered podiform chromitite, rutland ophiolite, Andaman, India. Canadian Mineralogist 49, 573-580.

Girardeau, J. \& Francheteau, J. (1993). Plagioclase-wehrlites and peridotites on the East Pacific Rise (Hess Deep) and the Mid-Atlantic Ridge (DSDP Site 334): evidence for magma percolation in the oceanic upper mantle. Earth and Planetary Science Letters 115, 137149.

Glennie, K. W., Boeuf, M. G. A., Clarke, M. H., Moody-Stuart, M., Pilaar, W. F. H. \& Reinhardt, B. M. (1973). Late Cretaceous nappes in Oman Mountains and their geologic evolution. AAPG Bulletin 57, 5-27.

Godard, M., Dautria, J. M. \& Perrin, M. (2003). Geochemical variability of the Oman ophiolite lavas: Relationship with spatial distribution and paleomagnetic directions. Geochemistry, Geophysics, Geosystems 4. 
Godard, M., Jousselin, D. \& Bodinier, J. L. (2000). Relationships between geochemistry and structure beneath a palaeo-spreading centre: A study of the mantle section in the Oman ophiolite. Earth and Planetary Science Letters 180, 133-148.

González-Jiménez, J. M., Griffin, W. L., Proenza, J. A., Gervilla, F., O’Reilly, S. Y., Akbulut, M., Pearson, N. J. \& Arai, S. (2014). Chromitites in ophiolites: How, where, when, why? Part II. The crystallization of chromitites. Lithos, 140-158.

Greenbaum, D. (1972). Magmatic processes at ocean ridges: evidence from the Troodos massif, Cyprus. Nature Physical Science 238, 18-21.

Holloway, J. R. (1973). The system pargasite-H2O-CO2: a model for melting of a hydrous mineral with a mixed-volatile fluid-I. Experimental results to 8 kbar. Geochimica et Cosmochimica Acta 37, 651-666.

Hoshide, T. \& Obata, M. (2009). Zoning and resorption of plagioclase in a layered gabbro, as a petrographic indicator of magmatic differentiation. Earth and Environmental Science Transactions of the Royal Society of Edinburgh 100, 1-15.

Hoshide, T. \& Obata, M. (2012). Amphibole-bearing multiphase solid inclusions in olivine and plagioclase from a layered gabbro: Origin of the trapped melts. Journal of Petrology 53, 419-449.

Hoshide, T. \& Obata, M. (2014). Spinel inclusions in olivine and plagioclase crystals in a layered gabbro: a marker and a tracer for primary phenocrysts in a differentiating magma reservoir. Contributions to Mineralogy and Petrology 168, 1049.

Irvine, T. N. (1975). Crystallization sequences in the Muskox intrusion and other layered intrusions-II. Origin of chromitite layers and similar deposits of other magmatic ores. Geochimica et Cosmochimica Acta 39.

Irvine, T. N. (1977a). Origin of chromitite layers in the Muskox intrusion and other stratiform intrusions: A new interpretation. Geology 5, 273-277. 
Irvine, T.N. (1977b). Chromite crystallization in the join $\mathrm{Mg}_{2} \mathrm{SiO}_{4}-\mathrm{CaMgSi}_{2} \mathrm{O}_{6}-\mathrm{CaAl}_{2}-\mathrm{Si}_{2} \mathrm{O}_{8^{-}}$ $\mathrm{MgCr}_{2} \mathrm{O}_{4}-\mathrm{SiO}_{2}$. Carnegie Instite. Washington Yearbook 76, 465-472.

Johan, Z., Dunlop, H., Le Bel, L., Robert, J. L. \& Volfinger, M. (1983). Origin of chromite deposits in ophiolitic complexes: evidence for a volatile- and sodium-rich reducing fluid phase. Fortschritte der Mineralogie 61, 105-107.

Johan, Z. \& Le Bel, L. (1978). Sur la genèse des couches et podes de chromite dans les complexes ophiolitiques. Rés. Sci. Tech. BRGM.

Johan, Z., Martin, R. F. \& Ettler, V. (2017). Fluids are bound to be involved in the formation of ophiolitic chromite deposits. European Journal of Mineralogy 29, 543-555.

Jousselin, D. \& Nicolas, A. (2000). The Moho transition zone in the Oman ophiolite-relation with wehrlites in the crust and dunites in the mantle. Marine Geophysical Researches 21, 229-241.

Jousselin, D., Nicolas, A. \& Boudier, F. (1998). Detailed mapping of a mantle diapir below a paleo-spreading center in the Oman ophiolite. Journal of Geophysical Research: Solid Earth 103, 18153-18170.

Kaczmarek, M. A. \& Müntener, O. (2008). Juxtaposition of melt impregnation and hightemperature shear zones in the upper mantle; field and petrological constraints from the Lanzo Peridotite (Northern Italy). Journal of petrology 49, 2187-2220.

Kelemen, P. B. (1990). Reaction between ultramafic rock and fractionating basaltic magma I. phase relations, the origin of calc-alkaline magma series, and the formation of discordant dunite. Journal of Petrology 31, 51-98.

Kelemen, P. B., Dick, H. J. B. \& Quick, J. E. (1992). Formation of harzburgite by pervasive melt/rock reaction in the upper mantle. Nature 358, 635-641.

Kelemen, P. B., Shimizu, N. \& Salters, V. J. (1995). Extraction of mid-ocean-ridge basalt from the upwelling mantle by focused flow of melt in dunite channels. Nature 375, 747-753. 
Koepke, J., Berndt, J., Horn, I., Fahle, J. \& Wolff, P. E. (2014). Partial melting of oceanic gabbro triggered by migrating water-rich fluids: a prime example from the Oman Ophiolite. Geological Society, London, Special Publications 392, 195-212.

Koepke, J., Botcharnikov, R. E. \& Natland, J. H. (2018). Crystallization of late-stage MORB under varying water activities and redox conditions: Implications for the formation of highly evolved lavas and oxide gabbro in the ocean crust. Lithos 323, 58-77.

Koepke, J., Feig, S. T. \& Snow, J. E. (2005). Hydrous partial melting within the lower oceanic crust. Terra Nova 17, 286-291.

Koga, K. T., Kelemen, P. B. \& Shimizu, N. (2001). Petrogenesis of the crust-mantle transition zone and the origin of lower crustal wehrlite in the Oman ophiolite. Geochemistry, Geophysics, Geosystems 2.

Latypov, R., Costin, G., Chistyakova, S., Hunt, E. J., Mukherjee, R. \& Naldrett, T. (2018). Platinum-bearing chromite layers are caused by pressure reduction during magma ascent. Nature communications 9, 1-7.

Leblanc, M. \& Ceuleneer, G. (1991). Chromite crystallization in a multicellular magma flow: Evidence from a chromitite dike in the Oman ophiolite. Lithos 27, 231-257.

Leblanc M., Ceuleneer G., Al Azri H. \& Jedwab, J. (1991). Concentration hydrothermale de Pd et de Pt dans les péridotites mantellaires du complexe ophiolitique d'Oman. Comptes Rendus Académie des Sciences 312, 1007-1012.

Legendre, O. (1982). Minéralogie et géochimie des platinoïdes dans les chromitites ophiolitiques. Comparaison avec d'autres types de concentrations en platinoïdes. Université Pierre et Marie Curie, Paris VI.

Li, C., Ripley, E. M., Sarkar, A., Shin, D. \& Maier, W. D. (2005). Origin of phlogopiteorthopyroxene inclusions in chromites from the Merensky Reef of the Bushveld Complex, South Africa. Contributions to Mineralogy and Petrology 150, 119-130. 
Lipin, B. R. (1993). Pressure increases, the formation of chromite seams, and the development of the ultramafic series in the Stillwater Complex, Montana. Journal of Petrology 34, 955976.

Locock, A. J. (2008). An Excel spreadsheet to recast analyses of garnet into end-member components, and a synopsis of the crystal chemistry of natural silicate garnets. Computers \& Geosciences 34, 1769-1780.

Lorand J.-P. (1988). Fe-Ni-Cu sulfides in tectonite peridotites from the Maqsad district, Sumail ophiolite, southern Oman: implications for the origin of the sulfide component in the oceanic upper mantle. Tectonophysics 151, 57-73.

Lorand, J.-P. \& Ceuleneer, G. (1989). Silicate and base-metal sulfide inclusions in chromites from the Maqsad area (Oman ophiolite, Gulf of Oman): A model for entrapment. Lithos 22, 173-190.

Maibam, B., Foley, S., Luguet, A., Jacob, D. E., Singh, T. B., Ray, D., Panda, D. K. \& Keppler, R. (2017). Characterisation of chromites, chromite hosted inclusions of silicates and metal alloys in chromitites from the Indo-Myanmar ophiolite belt of Northeastern India. Ore Geology Reviews 90, 260-273.

Mathez, E. A. \& Kinzler, R. J. (2017). Metasomatic chromitite seams in the Bushveld and Rum layered intrusions. Elements 13, 397-402.

Mathez, E. A. \& Webster, J. D. (2005). Partitioning behavior of chlorine and fluorine in the system apatite-silicate melt-fluid. Geochimica et Cosmochimica Acta 69, 1275-1286.

Matsukage, K. \& Arai, S. (1998). Jadeite, albite and nepheline as inclusions in spinel of chromitite from Hess Deep, equatorial Pacific: Their genesis and implications for serpentinite diapir formation. Contributions to Mineralogy and Petrology 131, 111-122.

McDonald, J. A. (1965). Liquid immiscibility as a factor in chromite seam formation in the Bushveld igneous complex. Economic Geology 60, 1674-1685. 
McElduff, B. \& Stumpfl, E. F. (1991). The chromite deposits of the Troodos complex, Cyprusevidence for the role of a fluid phase accompanying chromite formation. Miner. Mineralium Deposita 26, 307-318.

Meurer, W. P. \& Natland, J. H. (2001). Apatite compositions from oceanic cumulates with implications for the evolution of mid-ocean ridge magmatic systems. Journal of Volcanology and Geothermal Research.

Mombru, M. (2015). Diopsidites, granites et autres lithologies exotiques associées aux grandes zones de circulation hydrothermale dans le manteau océanique: Étude géochimique (isotopes, traces). Université Toulouse III - Paul Sabatier.

Mondal, S. K. \& Mathez, E. A. (2007). Origin of the UG2 chromitite layer, Bushveld Complex. Journal of Petrology 48, 495-510.

Monnier, C., Girardeau, J., Le Mée, L. \& Polvé, M. (2006). Along-ridge petrological segmentation of the mantle in the Oman ophiolite. Geochemistry, Geophysics, Geosystems 7.

Moores, E. M., \& Vine, F. J. (1971). The Troodos Massif, Cyprus and other ophiolites as oceanic crust: evaluation and implications. Philosophical Transactions of the Royal Society of London. Series A, Mathematical and Physical Sciences 268, 443-467.

Morgan, Z., Liang, Y. \& Kelemen, P. (2008). Significance of the concentration gradients associated with dunite bodies in the Josephine and Trinity ophiolites. Geochemistry, Geophysics, Geosystems, 9.

Morishita, T., Arai, S. \& Tamura, A. (2003). Petrology of an apatite-rich layer in the Finero phlogopite - peridotite, Italian Western Alps; implications for evolution of a metasomatising agent. Lithos 69, 37-49.

Naldrett, A. J., Wilson, A., Kinnaird, J., Yudovskaya, M., \& Chunnett, G. (2012). The origin of chromitites and related PGE mineralization in the Bushveld Complex: new 
mineralogical and petrological constraints. Mineralium Deposita 47, 209-232.

Nicolas, A. (1986). A melt extraction model based on structural studies in mantle peridotites. Journal of Petrology 27, 999-1022.

Nicolle, M., Jousselin, D., Reisberg, L., Bosch, D. \& Stephant, A. (2016). Major and trace element and $\mathrm{Sr}$ and $\mathrm{Nd}$ isotopic results from mantle diapirs in the Oman ophiolite: Implications for off-axis magmatic processes. Earth and Planetary Science Letters $\mathbf{4 3 7}$, $138-149$.

Nonnotte, P., Ceuleneer, G. \& Benoit, M. (2005). Genesis of andesitic-boninitic magmas at mid-ocean ridges by melting of hydrated peridotites: geochemical evidence from DSDP Site 334 gabbronorites. Earth and Planetary Science Letters 236, 632-653.

Peters, T. J. \& Kramers, J. D. (1974). Chromite deposits in the ophiolite complex of northern Oman. Mineralium Deposita 9, 253-259.

Plissart, G., Monnier, C., Diot, H., Mărunţiu, M., Berger, J. \& Triantafyllou, A. (2017). Petrology, geochemistry and Sm-Nd analyses on the Balkan-Carpathian Ophiolite (BCO - Romania, Serbia, Bulgaria): Remnants of a Devonian back-arc basin in the easternmost part of the Variscan domain. Journal of Geodynamics 105, 27-50.

Presnall, D. C. (2013). Phase Diagrams of Earth-Forming Minerals. Mineral physics and crystallography: A handbook of physical constants 2, 248-268.

Python, M. \& Ceuleneer, G. (2003). Nature and distribution of dykes and related melt migration structures in the mantle section of the Oman ophiolite. Geochemistry, Geophysics, Geosystems 4.

Python, M., Ceuleneer, G. \& Arai, S. (2008). Chromian spinels in mafic-ultramafic mantle dykes: Evidence for a two-stage melt production during the evolution of the Oman ophiolite. Lithos 106, 137-154.

Python, M., Ceuleneer, G., Ishida, Y., Barrat, J.-A. \& Arai, S. (2007). Oman diopsidites: a new 
lithology diagnostic of very high temperature hydrothermal circulation in mantle peridotite below oceanic spreading centres. Earth and Planetary Science Letters 255, 289-305.

Python, M., Yoshikawa, M., Shibata, T. \& Arai, S. (2011). Diopsidites and Rodingites: Serpentinisation and Ca-Metasomatism in the Oman Ophiolite Mantle. Dyke Swarms: Keys for Geodynamic Interpretations. Berlin, Heidelberg: Springer Berlin Heidelberg, $401-435$.

Quatrevaux, F. (1995). Etude pétrologique des péridotites des massifs de Maqsad et Wuqbah, ophiolite d'Oman. Université Paris Diderot Paris 7.

Quick, J. E. (1981a). Petrology and petrogenesis of the Trinity Peridotite, an upper mantle diapir in the Eastern Klamath Mountains, Northern California. Journal of Geophysical Research: Solid Earth 86, 11837-11863.

Quick, J. E. (1981b). The origin and significance of large, tabular dunite bodies in the Trinity peridotite, northern California. Contributions to Mineralogy and Petrology 78, 413-422.

Rabinowicz, M., Ceuleneer, G. \& Nicolas, A. (1987). Melt segregation and flow in mantle diapirs below spreading centres: evidence from the Oman ophiolite. Journal of Geophysical Research: Solid Earth 92, 3475-3486.

Rampone, E., Piccardo, G. B., Vannucci, R. \& Bottazzi, P. (1997). Chemistry and origin of trapped melts in ophioiitic peridotites. Geochimica et Cosmochimica Acta 61, 4557-4569.

Rioux, M., Bowring, S., Kelemen, P., Gordon, S., Miller, R. \& Dudás, F. (2013). Tectonic development of the Samail ophiolite: High-precision U-Pb zircon geochronology and Sm$\mathrm{Nd}$ isotopic constraints on crustal growth and emplacement. Journal of Geophysical Research: Solid Earth 118, 2085-2101.

Rioux, M., Garber, J., Bauer, A., Bowring, S., Searle, M., Kelemen, P. \& Hacker, B. (2016). Synchronous formation of the metamorphic sole and igneous crust of the Semail ophiolite: New constraints on the tectonic evolution during ophiolite formation from high-precision 
U-Pb zircon geochronology. Earth and Planetary Science Letters 451, 185-195.

Robinson, P. T., Trumbull, R. B., Schmitt, A., Yang, J.-S., Li, J.-W., Zhou, M.-F., Erzinger, J., Dare, S. \& Xiong, F. (2015). The origin and significance of crustal minerals in ophiolitic chromitites and peridotites. Gondwana Research 27, 486-506.

Rollinson, H. (2005). Chromite in the mantle section of the Oman ophiolite: A new genetic model. Island Arc, 542-550.

Rollinson, H. (2008). The geochemistry of mantle chromitites from the northern part of the Oman ophiolite: inferred parental melt compositions. Contributions to Mineralogy and Petrology 156, 273-288.

Rollinson, H. \& Adetunji, J. (2013). Mantle podiform chromitites do not form beneath midocean ridges: A case study from the Moho transition zone of the Oman ophiolite. Lithos $177,314-327$.

Rollinson, H., Mameri, L. \& Barry, T. (2018). Polymineralic inclusions in mantle chromitites from the Oman ophiolite indicate a highly magnesian parental melt. Lithos 310-311, 381391.

Rospabé, M. (2018). Etude pétrologique, géochimique et structurale de la zone de transition dunitique dans l'ophiolite d'Oman: Identification des processus pétrogénétiques à l'interface manteau/croûte. PhD thesis, Université Paul Sabatier, Toulouse III, 628 pp.

Rospabé, M., Benoit, M., Ceuleneer, G., Hodel, F. \& Kaczmarek, M.-A. (2018). Extreme geochemical variability through the dunitic transition zone of the Oman ophiolite: Implications for melt/fluid-rock reactions at Moho level beneath oceanic spreading centers. Geochimica et Cosmochimica Acta 234, 1-23.

Rospabé, M., Benoit, M., Ceuleneer, G., Kaczmarek, M.-A. \& Hodel, F. (2019a). Melt hybridization and metasomatism triggered by syn-magmatic faults within the Oman ophiolite: A clue to understand the genesis of the dunitic mantle-crust transition zone. 
Earth and Planetary Science Letters 516, 108-121.

Rospabé, M., Ceuleneer, G., Benoit, M., Abily, B. \& Pinet, P. (2017). Origin of the dunitic mantle-crust transition zone in the Oman ophiolite: The interplay between percolating magmas and high-temperature hydrous fluids. Geology 45, 471-474.

Rospabé, M., Ceuleneer, G., Benoit, M. \& Kaczmarek, M.-A. (2020). Composition gradients in silicate inclusions in chromites from the dunitic mantle-crust transition (Oman ophiolite) reveal high temperature fluid-melt-rock interaction controlled by faulting. Ofioliti 45, 103-114.

Rospabé, M., Ceuleneer, G., Granier, N., Arai, S. \& Borisova, A. Y. (2019b). Multi-scale development of a stratiform chromite ore body at the base of the dunitic mantle-crust transition zone (Maqsad diapir, Oman ophiolite): the role of repeated melt and fluid influxes. Lithos 350, 105235.

Sanfilippo, A., Dick, H. J. \& Ohara, Y. (2013). Melt-rock reaction in the mantle: mantle troctolites from the Parece Vela ancient back-arc spreading center. Journal of Petrology 54, 861-885.

Sanfilippo, A., Morishita, T., Kumagai, H., Nakamura, K., Okino, K., Hara, K., Tamura, A. \& Arai, S. (2015). Hybrid troctolites from mid-ocean ridges: inherited mantle in the lower crust. Lithos 232, 124-130.

Schandl, E. S., O'Hanley, D. S. \& Wicks, F. J. (1989). Rodingites in serpentinized ultramafic rocks of the Abitibi greenstone belt, Ontario. The Canadian Mineralogist 27, 579-591.

Schiano, P., Clocchiatti, R., Lorand, J.-P., Massare, D., Deloule, E. \& Chaussidon, M. (1997). Primitive basaltic melts included in podiform chromites from the Oman Ophiolite. Earth and Planetary Science Letters 146, 489-497.

Seyler, M., Toplis, M. J., Lorand, J. P., Luguet, A. \& Cannat, M. (2001). Clinopyroxene microtextures reveal incompletely extracted melts in abyssal peridotites. Geology 29, 155- 
158.

Spandler, C., Mavrogenes, J. \& Arculus, R. (2005). Origin of chromitites in layered intrusions: Evidence from chromite-hosted melt inclusions from the Stillwater Complex. Geology 33, 893-896.

Stolper, E. (1980). A phase diagram for mid-ocean ridge basalts: preliminary results and implications for petrogenesis. Contributions to Mineralogy and Petrology 74, 13-27.

Sun, C. \& Lissenberg, C. J. (2018). Formation of fast-spreading lower oceanic crust as revealed by a new Mg-REE coupled geospeedometer. Earth and Planetary Science Letters 487, $165-178$.

Takazawa, E., Abe, N., Seyler, M., Meurer, W. P. \& Kelemen, P. B. (2007). Hybridization of dunite and gabbroic materials in Hole 1271B from Mid-Atlantic Ridge 15 N: implications for melt flow and reaction in the upper mantle. Proceedings of the Ocean Drilling Program: Scientific Results 209, 1-23.

Talkington, R. W., Watkinson, D. H., Whittaker, P. J. \& Jones, P. C. (1984). Platinum-group minerals and other solid inclusions in chromite of ophiolitic complexes: Occurrence and petrological significance. TMPM Tschermaks Mineralogische und Petrographische Mitteilungen 32, 285-301.

Tamura, A., Morishita, T., Ishimaru, S., Hara, K., Sanfilippo, A., \& Arai, S. (2016). Compositional variations in spinel-hosted pargasite inclusions in the olivine-rich rock from the oceanic crust-mantle boundary zone. Contributions to Mineralogy and Petrology $171,39$.

Tamura, A., Morishita, T., Ishimaru, S. \& Arai, S. (2014). Geochemistry of spinel-hosted amphibole inclusions in abyssal peridotite: Insight into secondary melt formation in meltperidotite reaction. Contributions to Mineralogy and Petrology 167, 1-16.

Tippit, P. R., Pessagno, E. A. \& Smewing, J. D. (1981). The Biostratigraphy of Sediments in 
the Volcanic Unit of the Samail Ophiolite. Journal of Geophysical Research: Solid Earth 86, 2756-2762.

VanTongeren, J. A., Kelemen, P. B. \& Hanghøj, K. (2008). Cooling rates in the lower crust of the Oman ophiolite: Ca in olivine, revisited. Earth and Planetary Science Letters 267, 6982.

Varfalvy, V., Hébert, R. \& Bedard, J. H. (1996). Interactions between melt and upper-mantle peridotites in the North Arm Mountain massif, Bay of Islands ophiolite, Newfoundland, Canada: implications for the genesis of boninitic and related magmas. Chemical Geology 129, 71-90.

Wojtulek, P. M., Schulz, B., Delura, K. \& Dajek, M. (2019). Formation of chromitites and ferrogabbros in ultramafic and mafic members of the Variscan Ślęża ophiolite (SW Poland). Ore Geology Reviews 106, 97-112.

Yamasaki, T., Maeda, J. \& Mizuta, T. (2006). Geochemical evidence in clinopyroxenes from gabbroic sequence for two distinct magmatisms in the Oman ophiolite. Earth and Planetary Science Letters 251, 52-65.

Yao, Y., Takazawa, E., Chaterjee, S., Richard, A., Morlot, C., Créon, L., Al-Busaidi, S. \& Michibayashi, K. (2020). High resolution X-ray computed tomography and scanning electron microscopy studies of multiphase solid inclusions in Oman podiform chromitite: implications for post-entrapment modification. Journal of Mineralogical and Petrological Sciences 115, 247-260.

Wolff, P. E., Koepke, J. \& Feig, S. (2013). The reaction mechanism of fluid-induced partial melting of gabbro in the oceanic crust. European Journal of Mineralogy 25, 279-298.

Zagrtdenov, N. R., Ceuleneer, G., Rospabé, M., Borisova, A. Y., Toplis, M. J., Benoit, M. \& Abily, B. (2018). Anatomy of a chromitite dyke in the mantle/crust transition zone of the Oman ophiolite. Lithos 312, 343-357. 
Zhou, M. F., Robinson, P. T. \& Bai, W. J. (1994). Formation of podiform chromitites by melt/rock interaction in the upper mantle. Mineralium Deposita 29, 98-101.

Zihlmann, B., Müller, S., Coggon, R. M., Koepke, J., Garbe-Schönberg, D. \& Teagle, D. A. (2018). Hydrothermal fault zones in the lower oceanic crust: An example from Wadi Gideah, Samail ophiolite, Oman. Lithos 323, 103-124.

\section{FIGURE CAPTIONS}

Figure 1: (a) Simplified geological map of the Oman ophiolite. (b) Geological map of the Maqsad area in the Sumail massif, showing the location of the 275 dunite samples (red points) from the dunitic mantle-crust transition zone (DTZ) and of the chromitite and 9 mantle harzburgites (orange and white points) studied in this article for their chromite-hosted silicate inclusions. Are also shown the location of the main mantle and DTZ chromitite ore bodies in this area (white stars) and of minor mantle chromitites and remarkable chromite concentrations in the DTZ (e.g. seams (schlieren) and high amount of disseminated chromites in dunite, chromitite dikes; orange stars).

Figure 2: Overview of the texture of chromite in the Maqsad DTZ dunites, from the less (a) to the more concentrated ore (h). (a, b) Scattered, disseminated chromites in dunite. (c, d) Chromite seams, or schlieren, in dunites and (e-g) antinodular texture with the chromite crystallized interstitially between olivine grains. (h) Chromitite dike including dunitic xenoliths. (i, j) Chromite-rich layers cross-cut by a later N130-oriented olivine-gabbro dike (i) and cross-cut and resorbed by a gabbroic dike/impregnation (j).

Figure 3: Selection of photomicrographs showing an increasing amount of chromite in dunites from the Maqsad DTZ. Picture (a) illustrates that chromite is systematically located between 
olivine grains, frequently at grains triple junctions.

Figure 4: Photomicrographs (reflected light) of a few examples of inclusions in disseminated chromites in dunites from the Maqsad DTZ. Pictures are of samples 16OM124 (a), 15OM05 (b), 15OM110B (c and d), 15OM71A (e), 15OM90A (f), 16OM138 (g), 16OM124 (h) (b and h modified after Rospabé et al., 2017). Abbreviations are as follows: amph, amphibole; asp, aspidolite; cpx, clinopyroxene; diop, diopside; gt, grossular garnet; ne, nepheline; ol, olivine; opx, orthopyroxene; phl, phlogopite.

Figure 5: Relative frequency histograms of the identified silicate minerals in inclusion in disseminated chromites in 275 samples of dunites from the Maqsad DTZ. (a) Relative frequency of occurrence of each mineral phase as silicate inclusions in all samples ( $\mathrm{n}$ occurrences $=524 ; \mathrm{n}$ analyses $=1761)$. The relative frequency of occurrence has been calculated according to the presence (1) (i.e. what we call 'occurrence') or absence (0) of each phase in inclusion in each sample in order to determine how frequently a particular mineral is encountered in the total inclusion population. For example, amphibole was analysed 754 times in 185 samples, and diopside 84 times in 48 samples. Following this, we considered 185 occurrences of amphibole, 48 occurrences of diopside, and identified in this way a total of 524 occurrences all phases included, making amphibole and diopside representing $35.3 \%(185 / 524)$ and $9.2 \%(48 / 524)$ of the total respectively. Mineral phases are ranked in descending order of their relative frequency of occurrence. Abbreviations are as follows: alb, albitic feldspar; amph, amphibole; Cl-ap, chlorapatite; cpx, clinopyroxene; diop, diopside; gt, garnet; jad, jadeite; ne, nepheline; ol, olivine; opx, orthopyroxene; pct, pectolite; pl, plagioclase. (b) Relative frequency of occurrence of the main mineral phases in inclusion in each host dunite type. (c, d) Relative frequency 
histograms showing the evolution of the sum of individual occurrences of olivine + plagioclase + clinopyroxene on one hand, and of the sum of individual occurrences of orthopyroxene + amphibole + mica ( + diopside + garnet) on the other hand, according to the host rock type in which these silicate inclusions have been identified. Note that this evolution is related to the nature of the interstitial minerals in host rocks only, and is entirely independent from the modal content of these interstitial minerals (i.e. all samples showing the same mineralogy were classified in the same dunite type whatever their mode).

Figure 6: Vertical distribution of the inclusions in disseminated chromites along the Maqsad DTZ in comparison with the distribution of interstitial minerals in host dunites. Note that the occurrences of each mineral are plotted vertically as a function of the altitude of sampling for all 17 cross sections merged (i.e. the massif is tilted by less than $10^{\circ}$ ). Approximate stratigraphic depths cannot be calculated as the limits between the harzburgitic mantle section and the base of the transition zone, and between the top of the transition zone and the base of the lower crust, cannot be observed or deduced precisely in some cases (e.g. the top of the DTZ eroded or affected by faults, the base of the DTZ covered by quaternary sediments). To the left are shown the altitude intervals at which outcrop the main chromitiferous levels within the DTZ, with from the base to the top the Buri and Al Juyaynah areas, the stratiform chromitite and the nodular dike (see their location in Figure 1b). Abbreviations are the same as in Figures 4 and 5.

Figure 7: Major and minor element composition of chromites disseminated in the Maqsad DTZ dunites, from one DTZ chromitite sample, and of Cr-spinels in mantle harzburgites. Are represented (a) the $\mathrm{XCr}(100 \times$ molar $\mathrm{Cr} /(\mathrm{Cr}+\mathrm{Al}))$ as a function of the $\mathrm{XMg}(100 \times$ molar $\left.\mathrm{Mg} /\left(\mathrm{Mg}+\mathrm{Fe}^{2+}\right)\right)$ and (b) the $\mathrm{TiO}_{2}$ content as a function of the $\mathrm{XCr}$. The colour of the dots 
reflects the different types of host dunites depending on the nature of their interstitial minerals between olivine grains (see the legend below the two plots). Chromite in the chromitite and Crspinels in mantle harzburgites studied here are the big black diamonds and grey squares respectively. Compositions are compared to data from the literature for DTZ chromitites (small black diamonds) (Lorand and Ceuleneer, 1989; Leblanc and Ceuleneer, 1991; Borisova et al., 2012; Rollinson and Adetunji, 2013; Zagrtdenov et al., 2018; Rospabé et al., 2019b) and mantle harzburgites (small grey squares) (Quatrevaux, 1995; Gerbert-Gaillard, 2002; Monnier et al., 2006) from the Maqsad area.

Figure 8: Major and minor element composition of amphibole inclusions in disseminated chromites in the Maqsad DTZ dunites (number of analyses $n=754$ ), in one DTZ chromitite sample $(n=2)$, and in Cr-spinels in mantle harzburgites $(n=5)$. Are represented (a) the $\mathrm{Al}_{2} \mathrm{O}_{3}$ and (b) $\mathrm{TiO}_{2}$ contents as a function of the $\mathrm{XMg}\left(100 \times\right.$ molar $\left.\mathrm{Mg} /\left(\mathrm{Mg}+\mathrm{Fe}^{2+}\right)\right)$. Symbols are the same as in Figure 7. Compositions are compared to data from the literature for amphibole inclusions in DTZ chromitites from the Maqsad area (small black diamonds) (Lorand and Ceuleneer, 1989; Leblanc and Ceuleneer, 1991; Schiano et al., 1997; Borisova et al., 2012; Zagrtdenov et al., 2018; Rospabé et al., 2019b) and for interstitial amphibole in Maqsad DTZ dunites (small white dots) (Rospabé et al., 2017, 2018, 2019a).

Figure 9: Major and minor element composition of clinopyroxene inclusions in disseminated chromites in the Maqsad DTZ dunites ( $\mathrm{n}=593)$, in one DTZ chromitite sample $(\mathrm{n}=1)$, and in Cr-spinel in one mantle harzburgite $(n=1)$. Are represented (a) the $\mathrm{Al}_{2} \mathrm{O}_{3}$ and $(b) \mathrm{TiO}_{2}$ contents as a function of the $\mathrm{XMg}\left(100 \times\right.$ molar $\left.\mathrm{Mg} /\left(\mathrm{Mg}+\mathrm{Fe}^{2+}\right)\right)$. Symbols are the same as in Figure 7 . Compositions are compared to data from the literature for clinopyroxene inclusions in DTZ chromitites from the Maqsad area (small black diamonds) (Lorand and Ceuleneer, 1989; 
Leblanc and Ceuleneer, 1991; Borisova et al., 2012; Rospabé et al., 2019b) and for interstitial clinopyroxene in Maqsad DTZ dunites (small white dots) (Rospabé et al., 2017, 2018, 2019a).

Figure 10: Major and minor element composition of diopside inclusions in disseminated chromites in the Maqsad DTZ dunites $\left(\mathrm{n}=84\right.$ ). Are represented (a) the $\mathrm{Al}_{2} \mathrm{O}_{3}$ and (b) $\mathrm{TiO}_{2}$ contents as a function of the $\mathrm{XMg}\left(100 \times\right.$ molar $\left.\mathrm{Mg} /\left(\mathrm{Mg}+\mathrm{Fe}^{2+}\right)\right)$. Symbols are the same as in Figure 7. Compositions are compared to data from the literature for interstitial diopside in Maqsad DTZ dunites (small white dots) (Rospabé et al., 2017, 2018, 2019a) and for hydrothermal diopside in diopsidites and rodingites from the Oman ophiolite (black stars) (Python et al., 2007, 2011).

Figure 11: Major and minor element composition of mica inclusions in disseminated chromites in the Maqsad DTZ dunites $(n=119)$, in one DTZ chromitite sample $(n=7)$ and in Cr-spinel in one mantle harzburgite $(n=1)$. Are represented (a) the $\mathrm{K}_{2} \mathrm{O}$ content as a function of the $\mathrm{Na}_{2} \mathrm{O}$ content and (b) the $\mathrm{TiO}_{2}$ content as a function of the $\mathrm{XMg}\left(100 \times\right.$ molar $\left.\mathrm{Mg} /\left(\mathrm{Mg}+\mathrm{Fe}^{2+}\right)\right)$. Symbols are the same as in Figure 7. The black lines in panel (a) represent constant XNa ratio $(100 \times$ molar $\mathrm{Na} /(\mathrm{Na}+\mathrm{K}))$ values (in mol \%). Compositions are compared to data from the literature for mica inclusions in other DTZ chromitites from the Maqsad area (small black diamonds) (Lorand and Ceuleneer, 1989; Schiano et al., 1997; Borisova et al., 2012; Rospabé et al., 2019b).

Figure 12: Major and minor element composition of olivine, orthopyroxene and garnet inclusions in disseminated chromites in the Maqsad DTZ dunites $\left(\mathrm{n}_{\mathrm{ol}}=50, \mathrm{n}_{\mathrm{opx}}=63, \mathrm{n}_{\mathrm{gt}}=39\right)$, in one DTZ chromitite sample $\left(\mathrm{n}_{\mathrm{ol}}=5\right)$, and Cr-spinels in mantle harzburgites $\left(\mathrm{n}_{\mathrm{ol}}=6, \mathrm{n}_{\mathrm{opx}}=\right.$ 5). Are represented (a) the $\mathrm{NiO}$ content as a function of $\mathrm{Fo}\left(100 \times\right.$ molar $\left.\mathrm{Mg} /\left(\mathrm{Mg}+\mathrm{Fe}_{\text {total }}\right)\right)$ in 
olivine, (b) the $\mathrm{TiO}_{2}$ content as a function of the $\mathrm{XMg}\left(100 \times\right.$ molar $\left.\mathrm{Mg} /\left(\mathrm{Mg}+\mathrm{Fe}^{2+}\right)\right)$ in orthopyroxene and (c) the $\mathrm{TiO}_{2}$ content as a function of the $\mathrm{SiO}_{2}$ content in garnet. Symbols are the same as in Figure 7. In panel (a) the composition of olivine inclusions in disseminated chromites in dunites is compared to the one of olivine from nucleii around which grown the chromite nodules forming the nodular dike (small black diamonds) (Zagrtdenov et al., 2018), and to olivine constituting most of the matrix of host dunites (small white dots) (Rospabé et al., 2018, 2019a). In panel (b) the composition of orthopyroxene inclusions in disseminated chromites is compared to data from the literature for DTZ chromitites (small black diamonds) (Lorand and Ceuleneer, 1989; Borisova et al., 2012; Rospabé et al., 2019b), for interstitial orthopyroxene in DTZ dunites (small white dots) (Rospabé et al., 2017, 2018, 2019a), and for residual orthopyroxene in mantle harzburgites (small grey squares) (Quatrevaux, 1995; Gerbert-Gaillard, 2002; Monnier et al., 2006; Nicolle et al., 2016) from the Maqsad area. In panel (c) the composition of garnet inclusions in disseminated chromites is compared to the one of garnet inclusions from the nodular dike (Zagrtdenov et al., 2018) and the stratiform chromitite (Rospabé et al., 2019b) (small black diamonds), and of the one of interstitial garnet in the Maqsad DTZ dunites (small white dots) (Rospabé et al., 2017).

Figure 13: Vertical evolution of the composition of disseminated chromites and amphibole inclusions along the Maqsad DTZ, plotted as a function of the altitude of sampling. Data are plotted all together, without distinction between the 17 cross-sections sampled in the frame of this study. Are represented (a) the XMg $\left(100 \times\right.$ molar $\left.\mathrm{Mg} /\left(\mathrm{Mg}+\mathrm{Fe}^{2+}\right)\right), \mathrm{XCr}(100 \times$ molar $\mathrm{Cr} /(\mathrm{Cr}+\mathrm{Al}))$ and $\mathrm{TiO}_{2}$ content in chromite and (b) the $\mathrm{XMg}\left(100 \times\right.$ molar $\left.\mathrm{Mg} /\left(\mathrm{Mg}+\mathrm{Fe}^{2+}\right)\right)$, $\mathrm{TiO}_{2}, \mathrm{Na}_{2} \mathrm{O}$ and $\mathrm{F}$ contents in amphibole. Symbols are the same as in Figure 7. The vertical evolution of the composition of other silicates inclusions are provided in Electronic Appendix 2, and these variations are also shown separately according to the different types of host dunites. 


\section{ELECTRONIC SUPPLEMENTS}

Electronic supplement 1: Major element composition of the studied silicate inclusions and of their host chromites

Electronic supplement 2: Extended description of the major element mineral compositions (with extended versions of Figures 7, 8, 9, 10, 11, 12 and 13). 

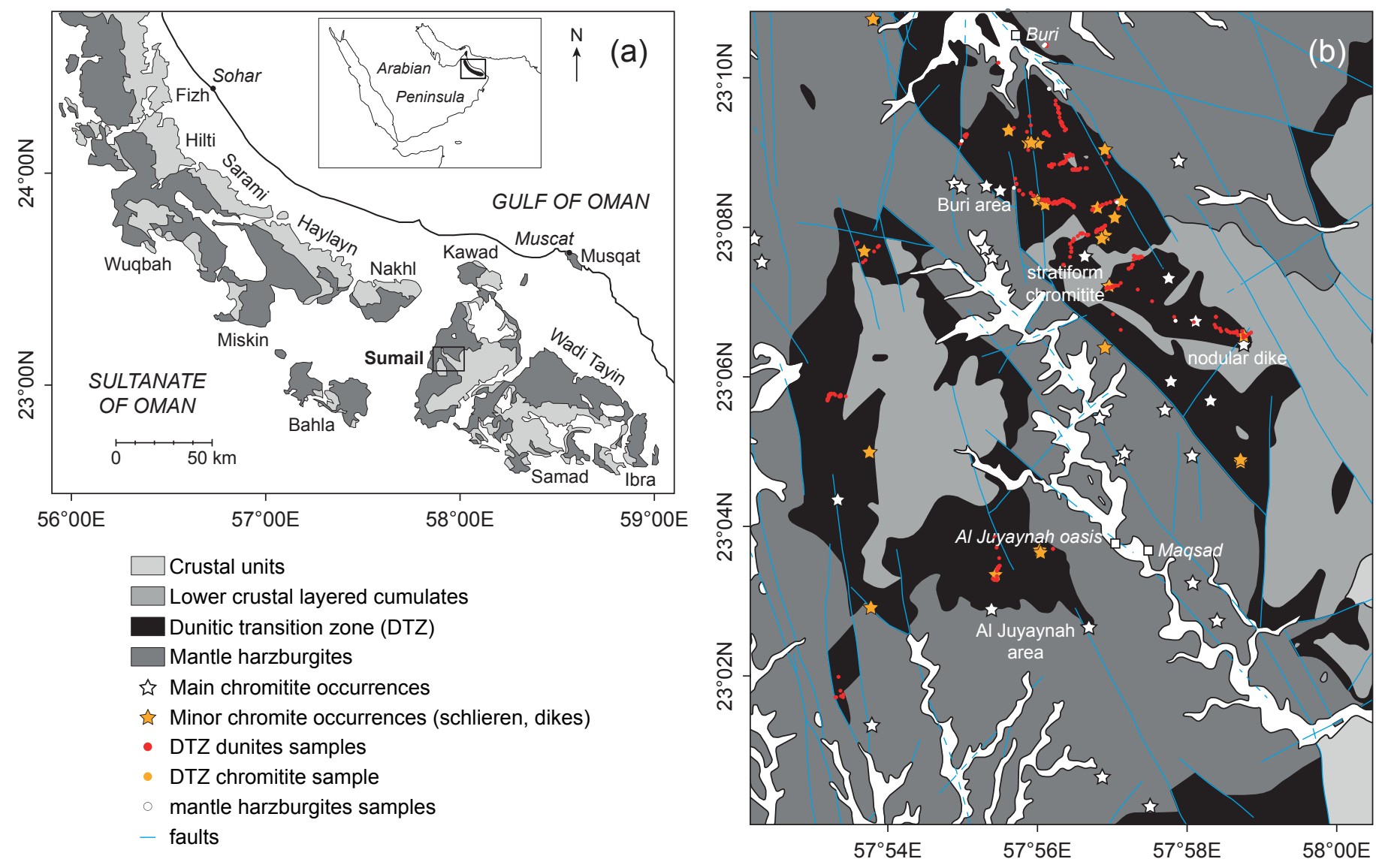

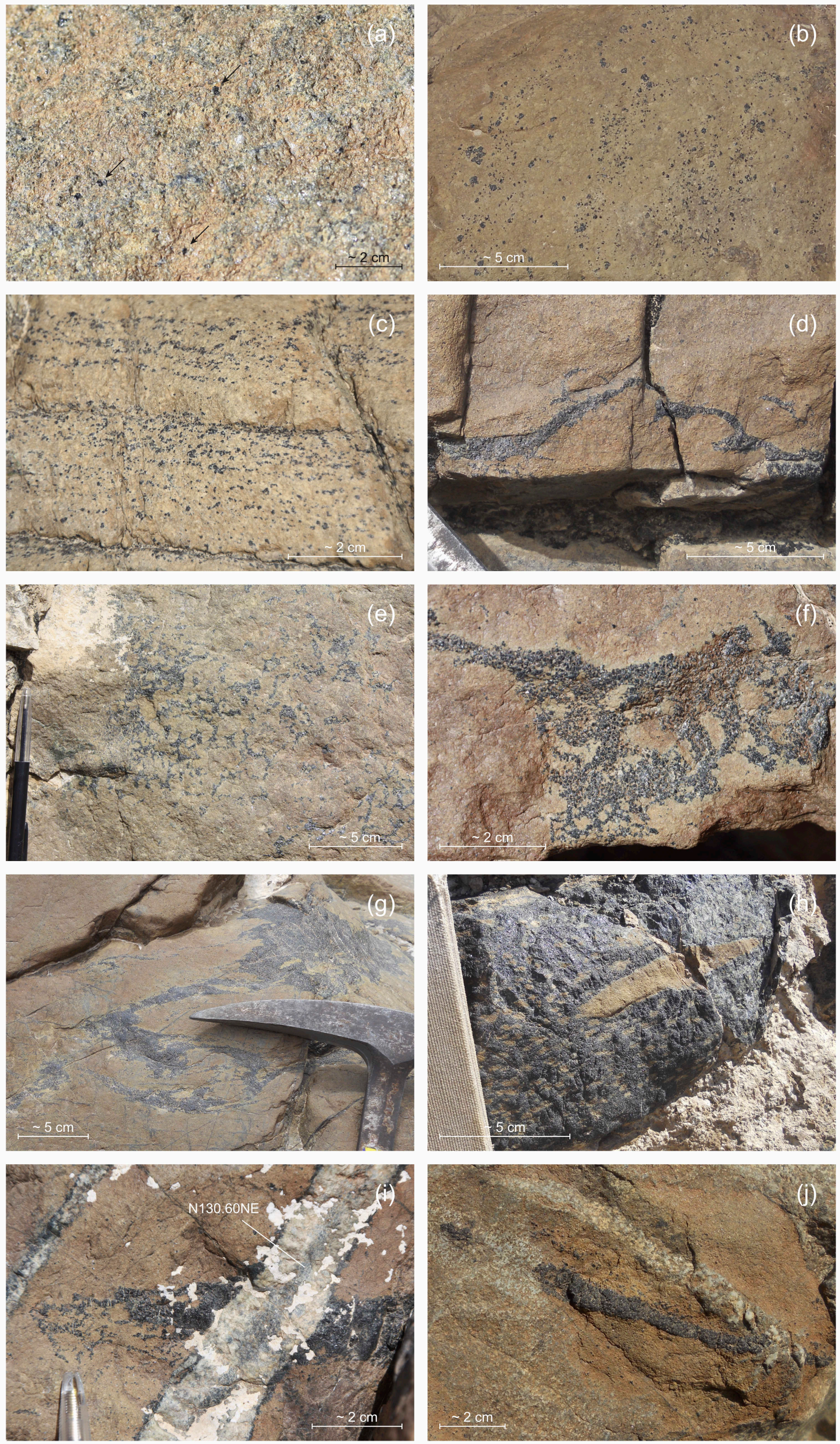

http://www.petrology.oupjournals.org/ 

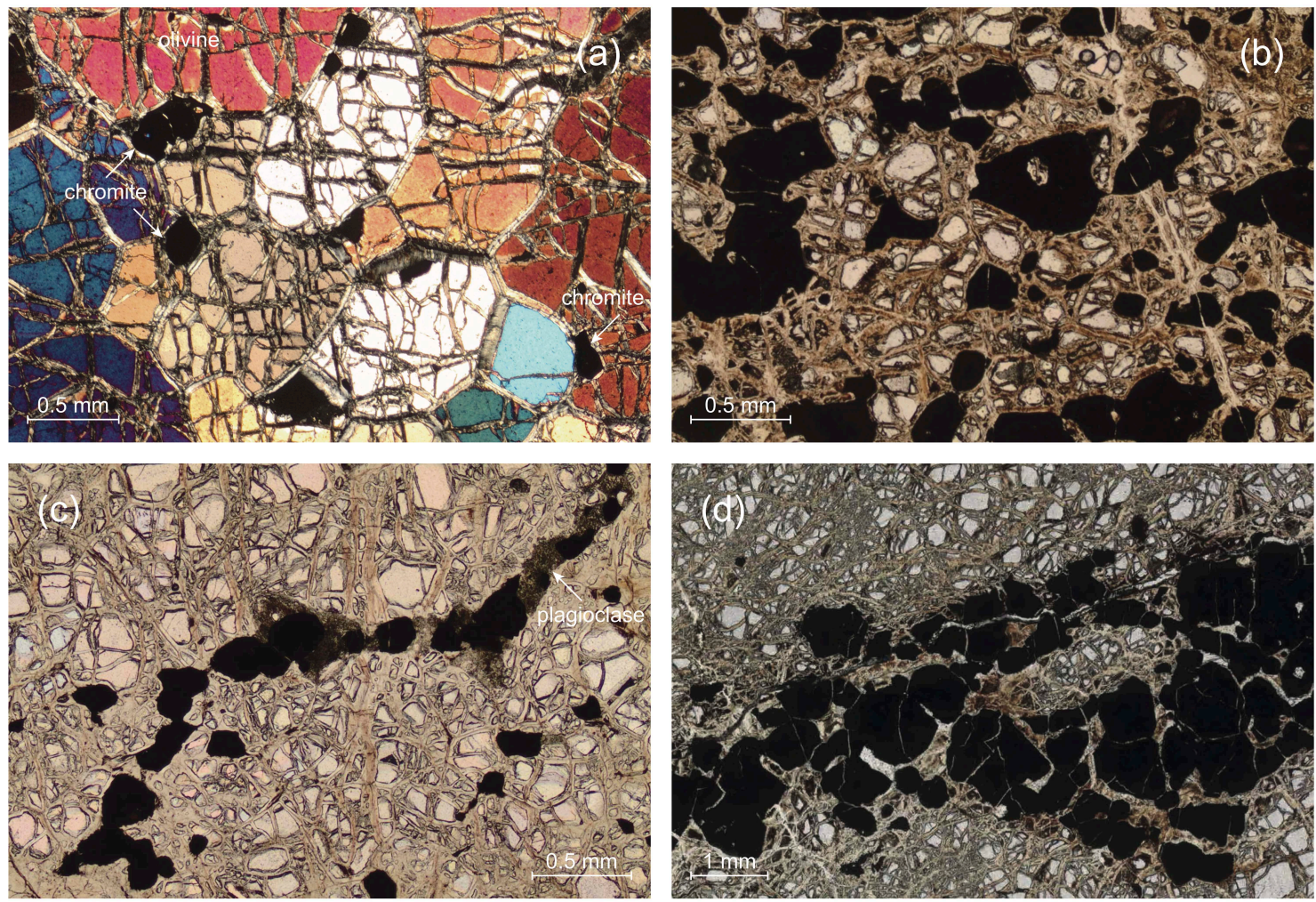

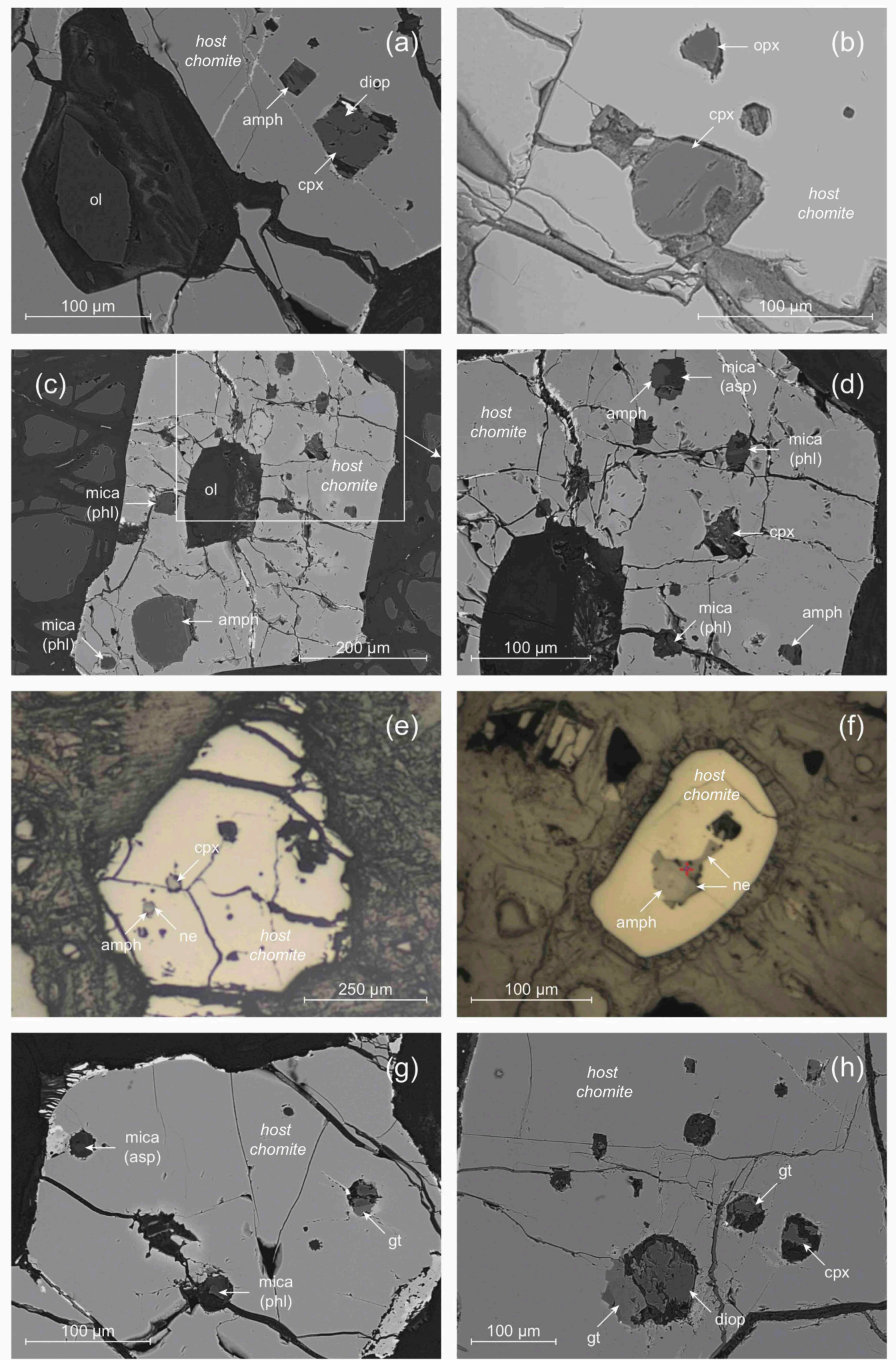

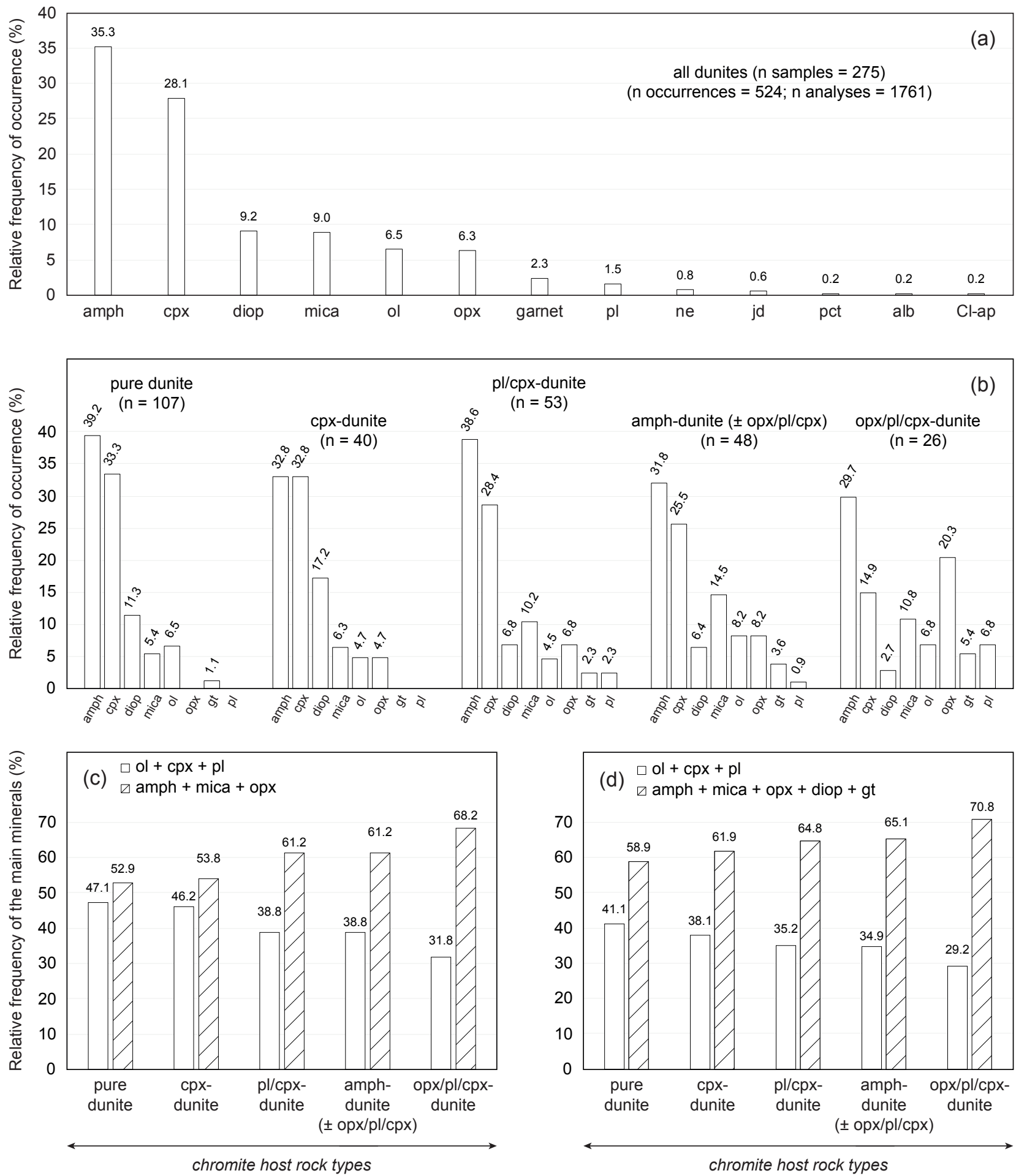


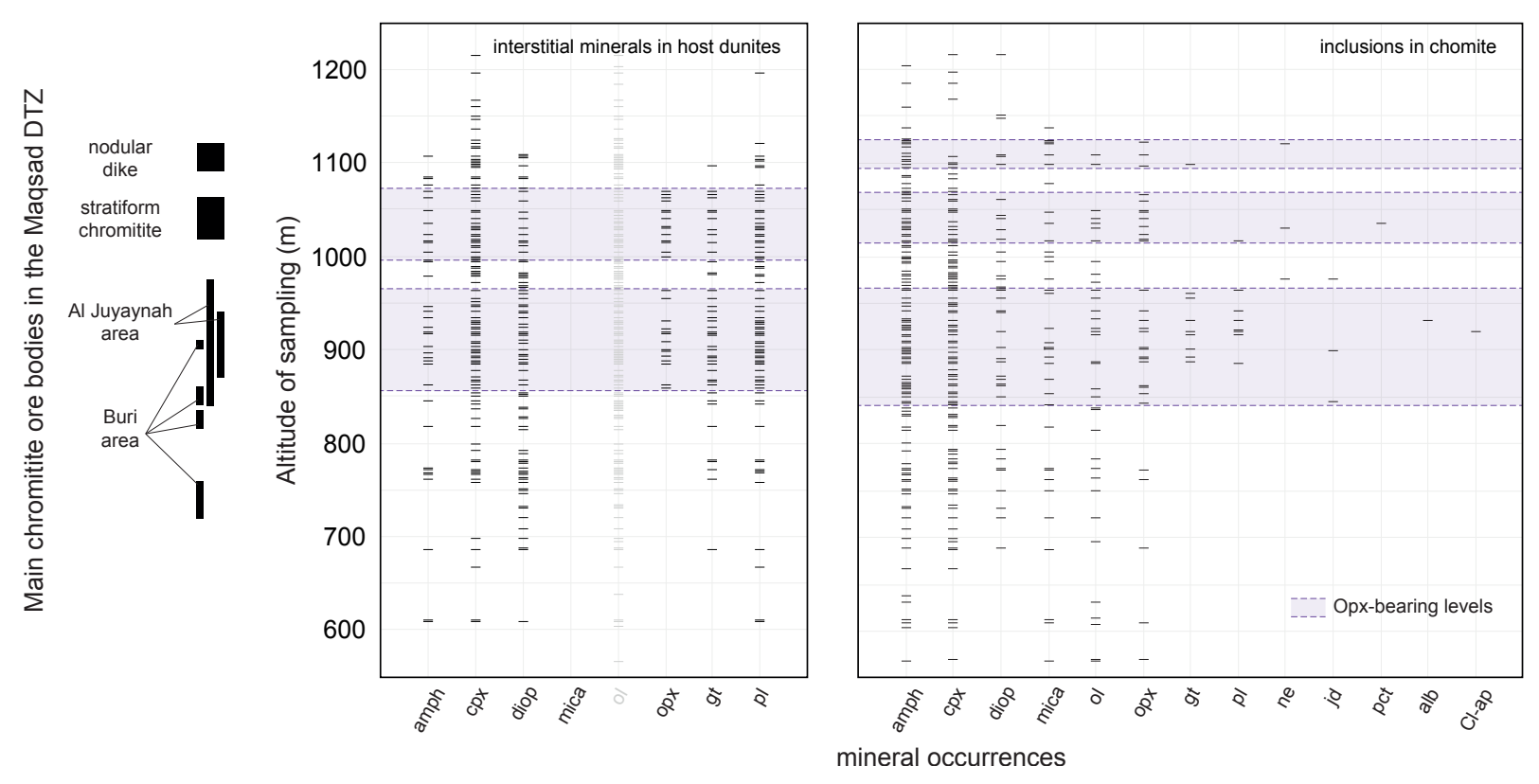



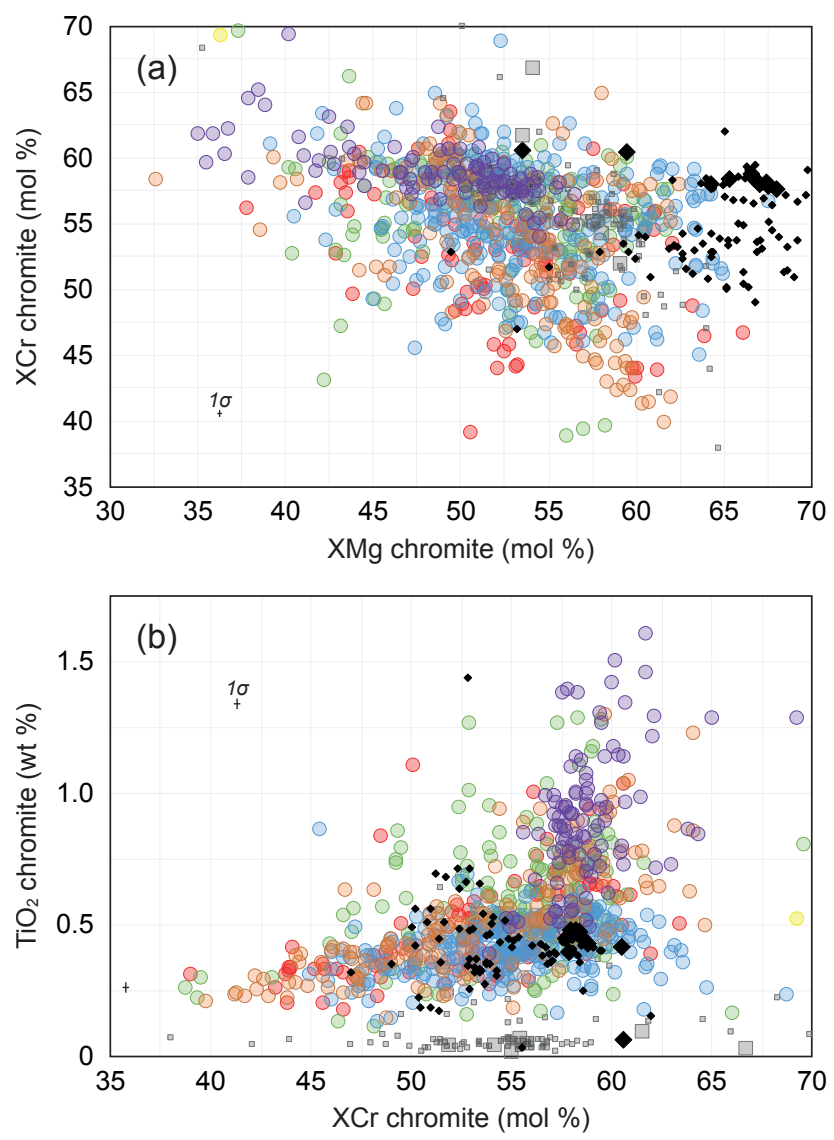

type of host rock:

o pure dunite

o cpx-bearing dunite

pl-bearing dunite

o $\mathrm{pl} / \mathrm{cpx}$-bearing dunite

disseminate chromites in amph-bearing dunite $( \pm \mathrm{opx} / \mathrm{pl} / \mathrm{cpx})$

$\circ$ opx/pl/cpx-bearing dunite

o chromite seams (schlieren)

- DTZ chromitite

$\square$ mantle harzburgite 

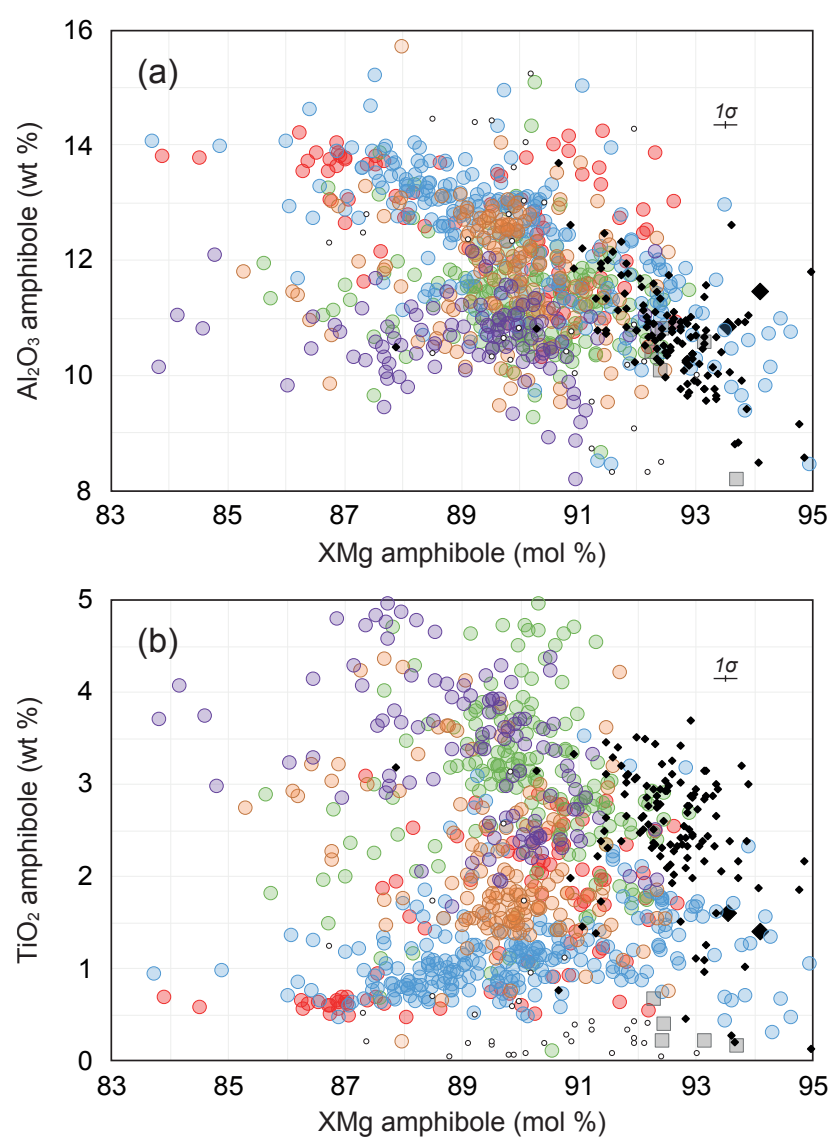

$$
\begin{aligned}
& \text { type of host rock: }
\end{aligned}
$$

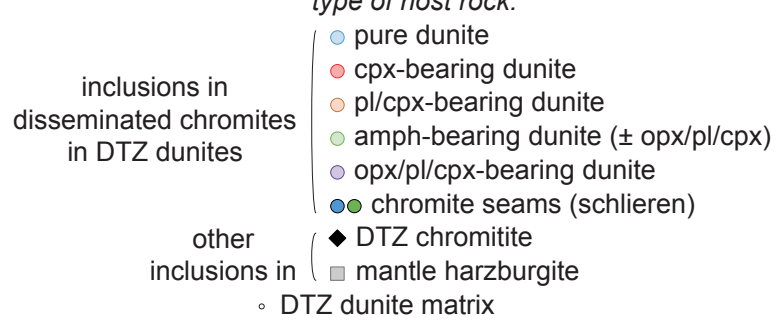



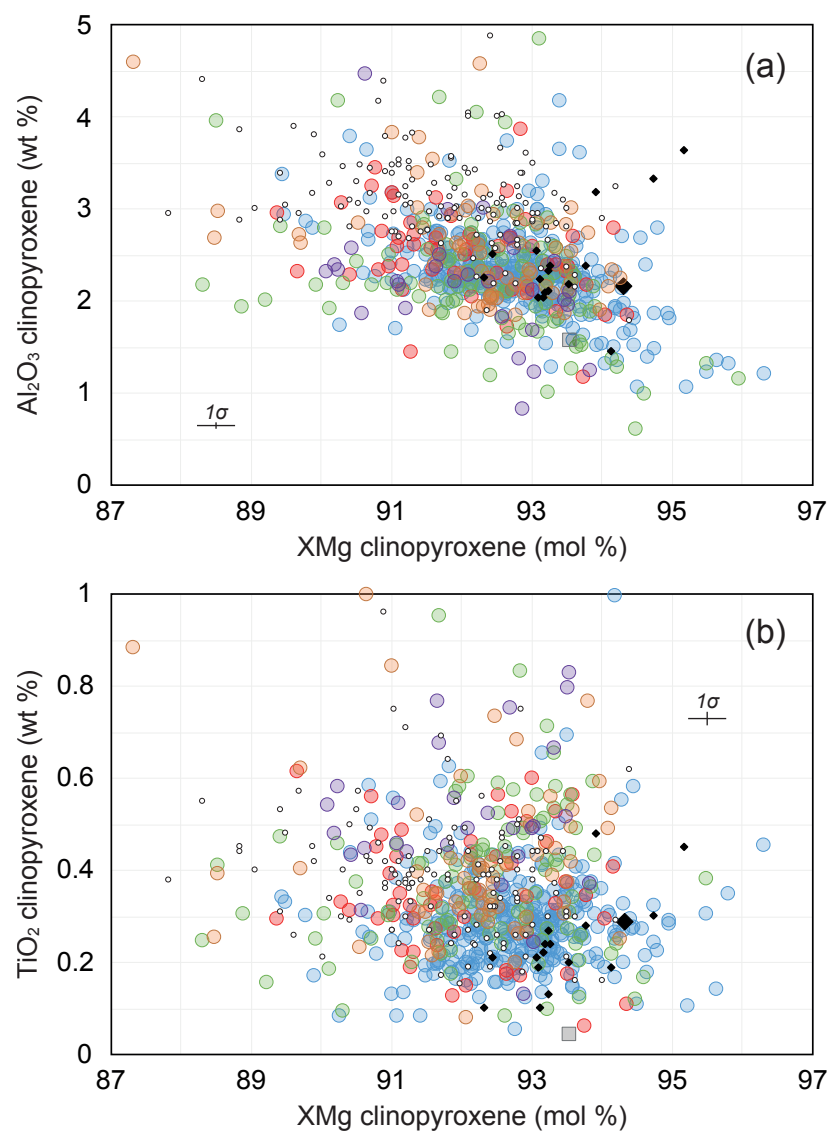

$$
\begin{aligned}
& \text { type of host rock: } \\
& \text { o pure dunite } \\
& \text { o cpx-bearing dunite } \\
& \begin{array}{l|l}
\text { inclusions in } & \circ \mathrm{cpx} \text {-bearing dunite } \\
& \mathrm{pl} / \mathrm{cpx} \text {-bearing dunite }
\end{array} \\
& \text { disseminated chromites amph-bearing dunite }( \pm \text { opx/pl/cpx) } \\
& \text { in DTZ dunites } \quad \circ \text { opx/pl/cpx-bearing dunite } \\
& \text { oo chromite seams (schlieren) } \\
& \text { other DTZ chromitite } \\
& \text { inclusions in } \square \text { mantle harzburgite } \\
& \text { - DTZ dunite matrix }
\end{aligned}
$$



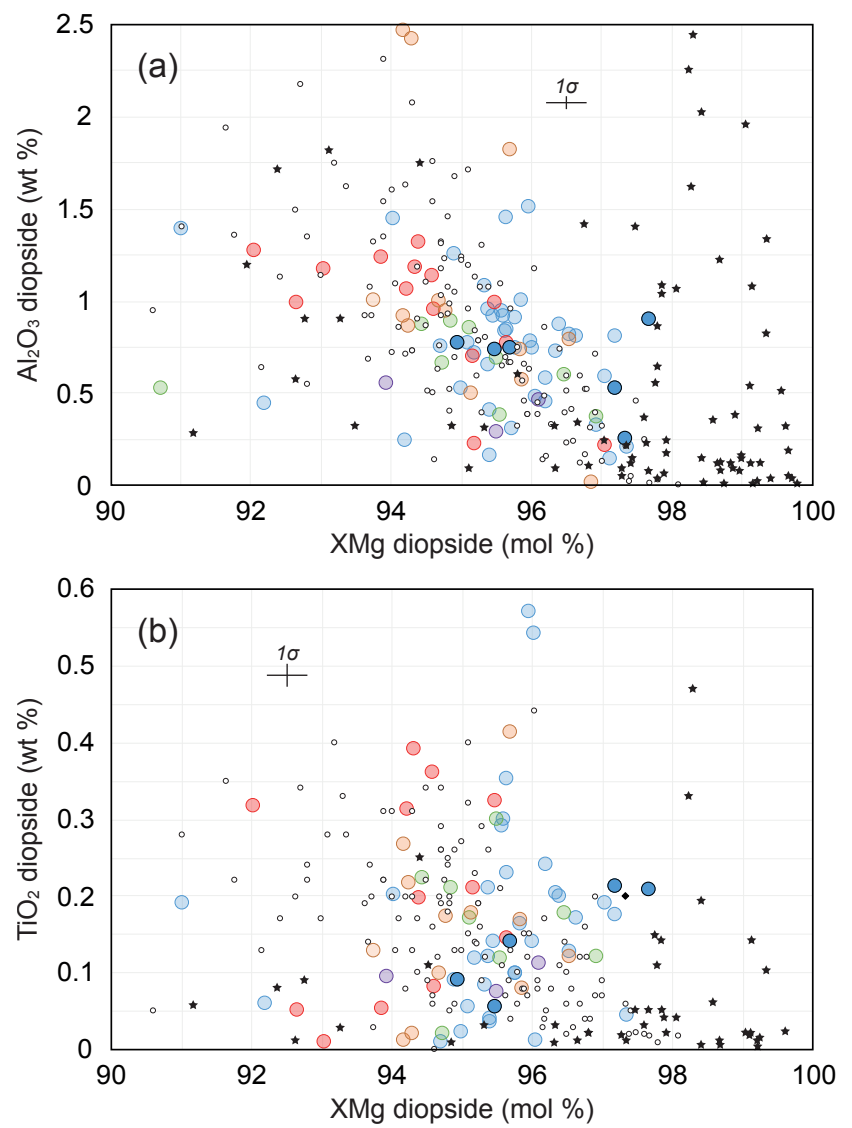

$$
\begin{aligned}
& \text { type of host rock: } \\
& \begin{array}{c|l}
\begin{array}{c}
\text { inclusions in } \\
\text { disseminated chromites } \\
\text { in DTZ dunites }
\end{array} & \begin{array}{l}
\circ \text { pure dunite } \\
\circ \mathrm{cpx}-\text { bearing dunite } \\
\circ \mathrm{pl} / \mathrm{cpx} \text {-bearing dunite } \\
\circ \text { amph-bearing dunite }( \pm \mathrm{opx} / \mathrm{pl} / \mathrm{cpx}) \\
0 \text { opx/pl/cpx-bearing dunite } \\
\text { o chromite seams (schlieren) }
\end{array} \\
\text {.DTZ dunite matrix }
\end{array}
\end{aligned}
$$



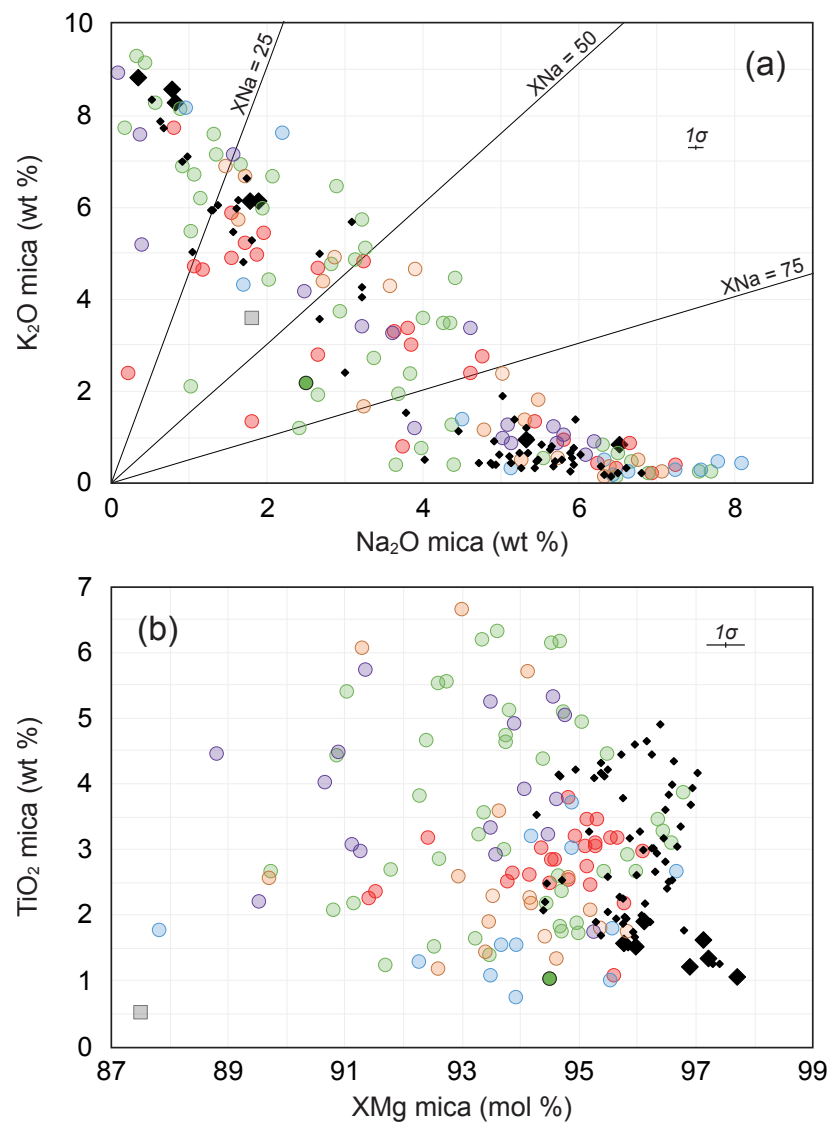

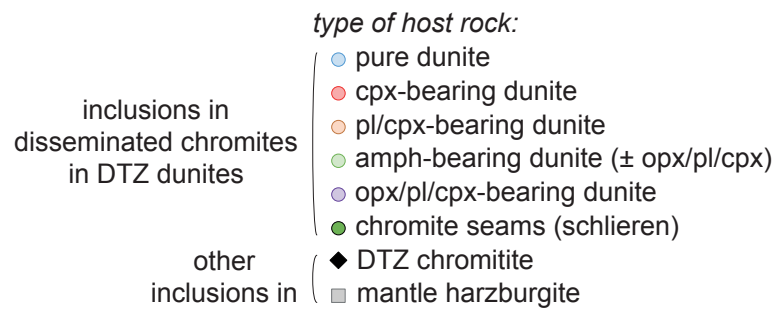



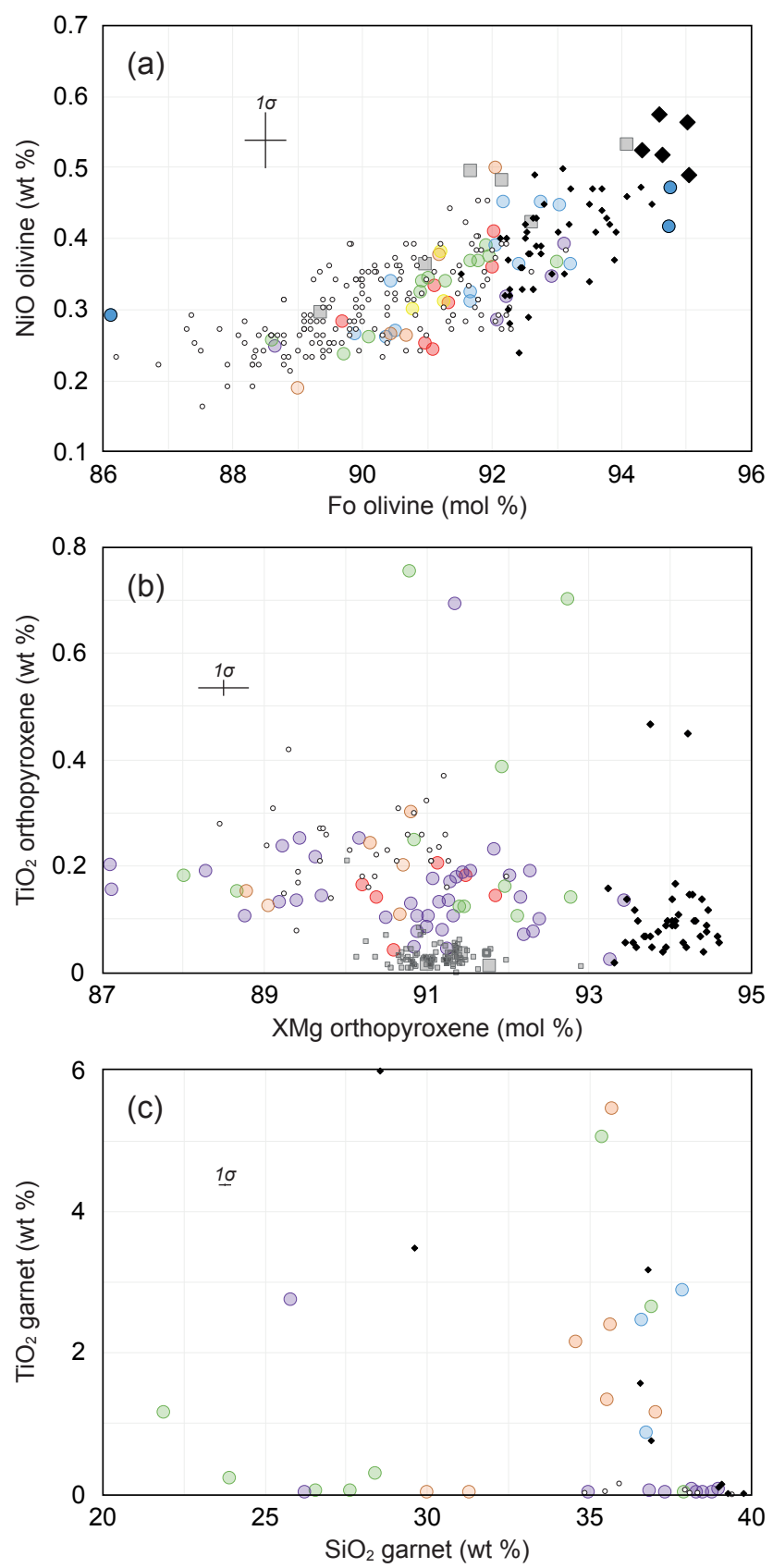

$$
\begin{aligned}
& \text { type of host rock: } \\
& \begin{array}{c|c}
\begin{array}{c}
\text { inclusions in } \\
\text { disseminated chromites } \\
\text { in DTZ dunites }
\end{array} & \begin{array}{l}
\text { p pure dunite } \\
0 \text { cpx-bearing dunite } \\
\text { pl-bearing dunite } \\
\text { pl/cpx-bearing dunite } \\
0 \text { amph-bearing dunite }( \pm \text { opx/pl/cpx) } \\
0 \text { opx/pl/cpx-bearing dunite } \\
\text { o chromite seams (schlieren) }
\end{array} \\
\text { other } & \begin{array}{l}
\text { DTZ chromitite } \\
\text { mantle harzburgite }
\end{array} \\
\text { inclusions in } & \text { DTZ dunite matrix }
\end{array}
\end{aligned}
$$




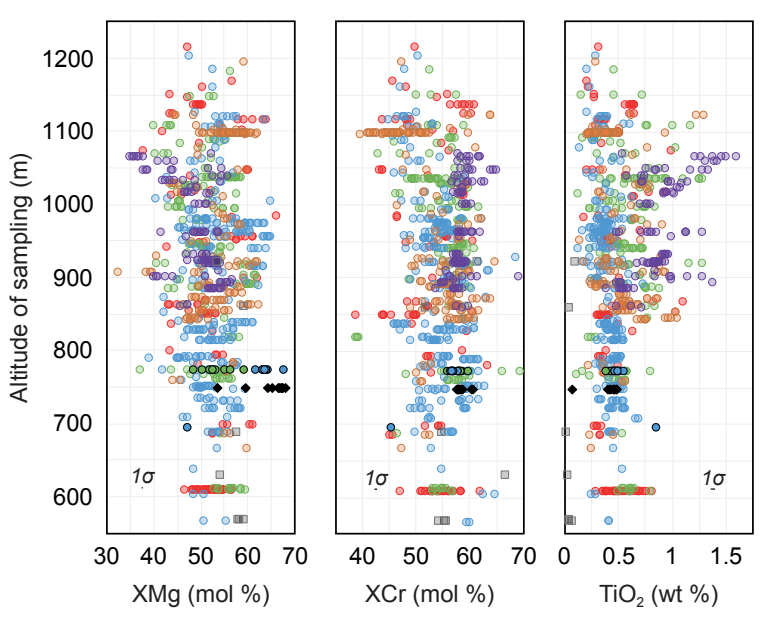

(a) host chromite pure dunite pl-bearing dunite amph-bearing dunite (t

- cpx-bearing dunite $\circ \mathrm{pl} / \mathrm{cpx}$-bearing dunite $\circ$ opx/pl/cpx-bearing dunite
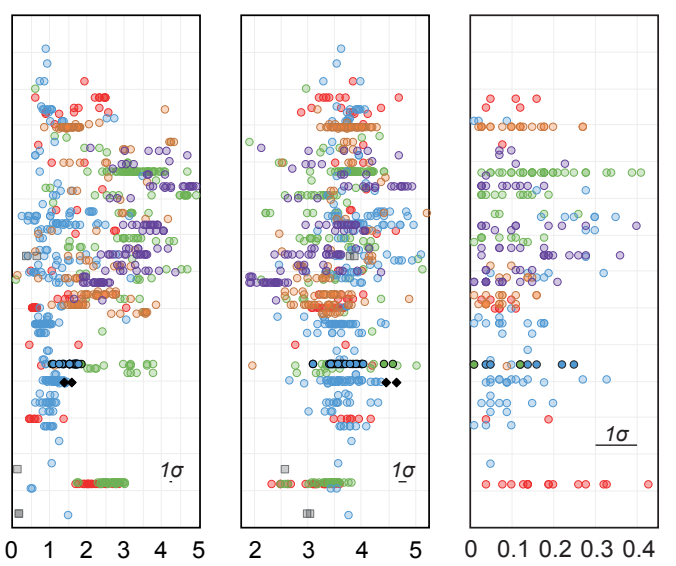

$\mathrm{TiO}_{2}(w \mathrm{w} \%)$

$\mathrm{Na}_{2} \mathrm{O}($ wt \%)

$\mathrm{F}(\mathrm{wt} \%)$

(b) amphibole inclusions chromite seams (schlieren)
DTZ chromitite $\square$ mantle harzburgite 